\title{
Xenotransplantation: Current Status in Preclinical Research
}

\section{OPEN ACCESS}

Edited by:

Gilles Blancho,

Université de Nantes, France

Reviewed by:

Mahzad Akbarpour School of Medicine, Northwestern University, United States

Orestis Argyros,

GlaxoSmithKline, United Kingdom

*Correspondence:

Chuan Qin

qinchuan@pumc.edu.cn

Specialty section:

This article was submitted to Alloimmunity and Transplantation,

a section of the journal

Frontiers in Immunology

Received: 15 October 2019 Accepted: 16 December 2019

Published: 23 January 2020

Citation:

Lu T, Yang B, Wang R and Qin C (2020) Xenotransplantation: Current

Status in Preclinical Research.

Front. Immunol. 10:3060. doi: 10.3389/fimmu.2019.03060

\author{
Tianyu Lu ${ }^{1,2,3}$, Bochao Yang ${ }^{1,2,3}$, Ruolin Wang ${ }^{1,2,3}$ and Chuan Qin ${ }^{1,2,3 *}$ \\ 1 Institute of Laboratory Animal Sciences, Chinese Academy of Medical Sciences and Comparative Medicine Center, Peking \\ Union Medical College, Beijing, China, ${ }^{2}$ NHC Key Laboratory of Human Disease Comparative Medicine, The Institute of \\ Laboratory Animal Sciences, Chinese Academy of Medical Sciences \& Peking Union Medical College, Beijing, China, \\ ${ }^{3}$ Beijing Engineering Research Center for Experimental Animal Models of Human Critical Diseases, Beijing, China
}

The increasing life expectancy of humans has led to a growing numbers of patients with chronic diseases and end-stage organ failure. Transplantation is an effective approach for the treatment of end-stage organ failure; however, the imbalance between organ supply and the demand for human organs is a bottleneck for clinical transplantation. Therefore, xenotransplantation might be a promising alternative approach to bridge the gap between the supply and demand of organs, tissues, and cells; however, immunological barriers are limiting factors in clinical xenotransplantation. Thanks to advances in gene-editing tools and immunosuppressive therapy as well as the prolonged xenograft survival time in pig-to-non-human primate models, clinical xenotransplantation has become more viable. In this review, we focus on the evolution and current status of xenotransplantation research, including our current understanding of the immunological mechanisms involved in xenograft rejection, genetically modified pigs used for xenotransplantation, and progress that has been made in developing pig-to-pig-to-non-human primate models. Three main types of rejection can occur after xenotransplantation, which we discuss in detail: (1) hyperacute xenograft rejection, (2) acute humoral xenograft rejection, and (3) acute cellular rejection. Furthermore, in studies on immunological rejection, genetically modified pigs have been generated to bridge cross-species molecular incompatibilities; in the last decade, most advances made in the field of xenotransplantation have resulted from the production of genetically engineered pigs; accordingly, we summarize the genetically modified pigs that are currently available for xenotransplantation. Next, we summarize the longest survival time of solid organs in preclinical models in recent years, including heart, liver, kidney, and lung xenotransplantation. Overall, we conclude that recent achievements and the accumulation of experience in xenotransplantation mean that the first-in-human clinical trial could be possible in the near future. Furthermore, we hope that xenotransplantation and various approaches will be able to collectively solve the problem of human organ shortage.

Keywords: immunological rejection, coagulation dysfunction, genetically modified pigs, non-human primate, xenotransplantation 


\section{INTRODUCTION}

Transplantation is an effective approach for the treatment of end-stage organ failure. However, the imbalance between supplement and demand for human organs is a bottleneck for clinical transplantation. According to the US Government Information on Organ Donation and Transplantation, more than 113,000 candidates were on the transplant waiting list as of January 2019, while only 36,528 transplants were performed in 2018 [data available from URL: https://www.organdonor. gov/statistics-stories/statistics.html (accessed June 29, 2019)]. In China, more than 300,000 people are on the waiting list, but only $\sim 16,000$ organs are available each year (1). Xenotransplantation may be an alternative solution to this grave problem. The World Health Organization (WHO) defines xenotransplantation as "any procedure that involves the transplantation, implantation or infusion into a human recipient of either: (i) live cells, tissues, or organs from a non-human animal source; or (ii) human body fluids, cells, tissues or organs that have had ex vivo contact with live non-human animal cells, tissues or organs" [Xenotransplantation, WHO, Geneva, Switzerland 2016. Available from URL: http://www.who.int/transplantation/xeno/ en/ (accessed 2019 June 29)].

Xenotransplantation is not a new concept. It was first mentioned in 1667 in the context of the xenotransfusion of blood from lambs to humans (2). Clinical use of animal organs has also been documented, such as the transplantation of a rabbit kidney to a human in 1905 (3). Because nonhuman primates (NHPs) are phylogenetically closer to humans than are other species, several trials involving the kidneys, hearts, and livers of NHPs were conducted from the 1920s to 1990s $(4,5)$. However, researchers found that NHPs were not suitable source animals for clinical xenotransplantation because of ethical concerns, the high risk of cross-species transmission of infections to humans, difficulties in breeding, organ size disparities, and other impracticalities (6). Since the 1990s, researchers have attempted to use pigs as the source animal for xenotransplantation, and the pig is currently considered the most appropriate candidate species. Reasons for selecting the pig as a source animal include the pig's relatively large litter size and short maturation period, its size and physiological similarity to humans, the low risk of xenozoonosis, and the readily application of genetic engineering techniques to produce porcine organs that are resistant to rejection (7). However, the genetic discrepancy between pigs and humans has resulted in barriers for xenotransplantation, including immunological rejection, and risk of xenozoonosis. As with human allotransplants, xenotransplants are prone to immunological rejection. However, a vascularized porcine organ is more vigorously rejected in comparison with the current reaction observed in allotransplants because of the genetic distance between pigs and primates. Thanks to genetically modified pigs and immunosuppressive therapy, survival time results for xenografts have improved considerably in preclinical xenotransplantation models. These results in NHP models indicate that the use of xenotransplantation in clinical applications is approaching.
In this article, we (a) describe our understanding of immunological rejection responses in xenotransplantation, (b) summarize the genetically modified pigs used for xenotransplantation, and (c) report the current survival time of xenografts in pig-to-NHP models. On the basis of this considerable progress, we hold that clinical application of xenotransplantation will soon be a reality.

\section{IMMUNOLOGICAL BARRIERS FOR XENOTRANSPLANTATION}

Some decellularized extracellular matrix products, such as cornea and cardiac valves, have been used in clinical settings $(8,9)$. However, these grafts have largely been structural tissues from which the pig cells have been removed. The tissues are repopulated with human recipient cells after transplantation. Vascularized organ and cell transplantation have been impeded by rejection. Immune responses following discordant xenotransplantation include both acquired immunity and innate immunity, in which natural antibodies, complement, natural killer (NK) cells, and macrophages all play interdependent roles. Three main types of rejection can occur in a successive manner: (i) hyperacute xenograft rejection, (ii) acute humoral xenograft rejection, and (iii) acute cellular rejection (10). In addition to immunological rejection, coagulation dysregulation, and inflammatory response have become more prominent, leading to xenograft failure.

\section{Hyperacute Rejection and Acute Humoral Xenograft Rejection}

When a wild-type pig organ is transplanted into a human or an NHP, the graft is rapidly destroyed, usually within minutes to hours, in a process known as hyperacute rejection (HAR) (11). HAR is a type of humoral rejection and is mediated by preformed antibodies that naturally pre-exist in the recipient. The binding of preformed antibodies to the xenoantigenic epitopes on porcine endothelial cells triggers the activation of complement proteins. Activated complement cause further activation and lysis of endothelial cells, leading to the destruction of the graft vasculature and subsequent graft failure (Figure 1A) (12). HAR is characterized histologically by disruption of vascular integrity, edema, thrombosis, and hemorrhage with widespread vascular deposition of antibodies and terminal complement products $(13,14)$.

HAR can be avoided by depleting the antipig antibodies or inhibiting complement activation in the recipient by plasmapheresis (15). Although these measures lead to graft survival prolonged beyond $24 \mathrm{~h}$ and sometimes for a week or more, the recovered level of antibody has resulted in graft failure, which is known as acute humoral xenograft rejection (AHXR), also referred as "acute vascular rejection" or "delay xenograft rejection" (14). AHXR is a phenomenon caused by a combination of humoral and cellar immune responses, combined with activated endothelia, and inflammation (16, 17) (Figure 1B). Classic features of severe AHXR are massive interstitial hemorrhage, infarction, necrosis, thrombosis, and loss 

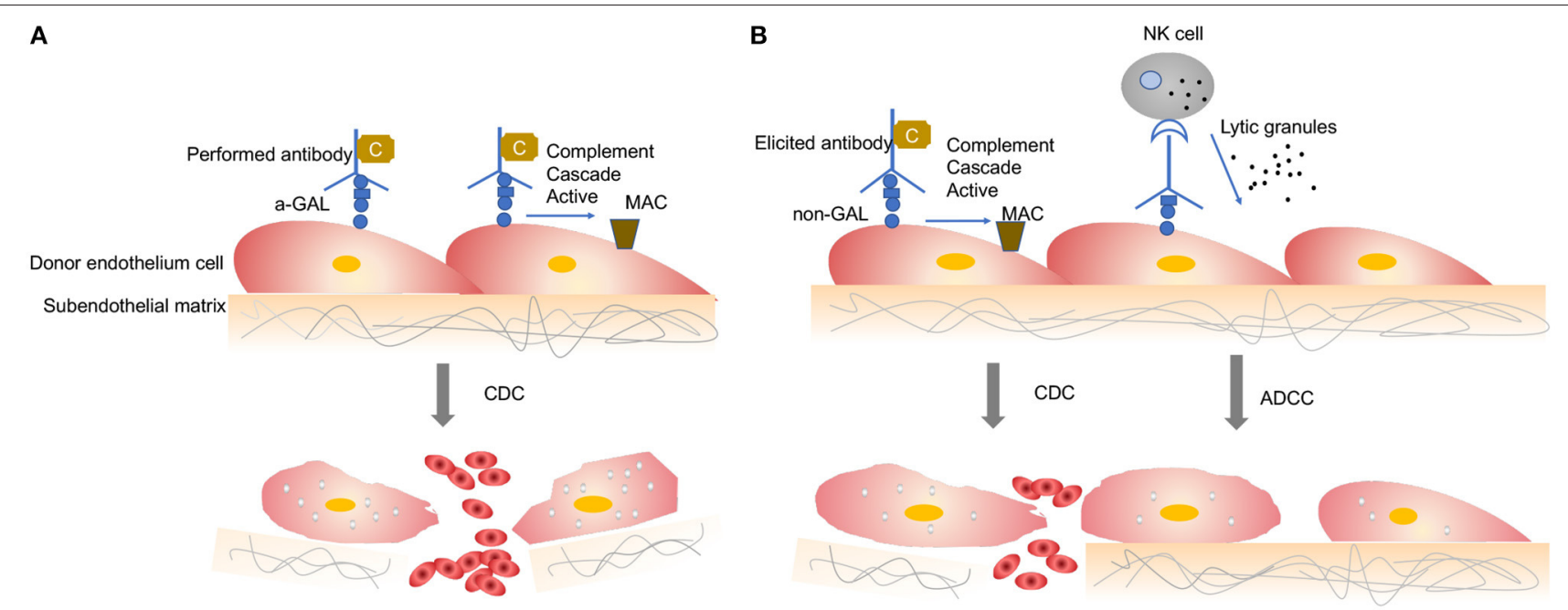

FIGURE 1 | Antibody-mediated xenograft rejection. (A) Hyperacute rejection. Hyperacute rejection of vascularized porcine xenografts in untreated primates is triggered by the binding of preformed antibodies to the xenoantigenic epitopes (predominantly $\alpha 1,3 \mathrm{Gal}$ ) on the surface of donor endothelial cells. The binding antibody deposition induces the activation of complement proteins and formation of the membrane attack complex, leading to lysis of endothelial cells destruction of the graft vasculature and subsequent graft failure. Loss of endothelial barrier function contributes to bleeding, leading to tissue ischemia and necrosis. (B) Acute humoral xenograft rejection. Acute humoral xenograft rejection can be induced by low levels of natural and elicited xenoreactive antibodies. The binding of xenoreactive antibodies to endothelial cells results in complement activation, vascular endothelial activation, and injury caused by antibody-dependent cell-mediated cytotoxicity. Innate immune cells are recruited by activated endothelia and proinflammatory signals. Simultaneously, human antipig antibodies are triggered by natural killer cells and macrophages. MAC, membrane attack complex; C, Complement; NK, natural killers.

of tubules with polymorph infiltration and massive deposition of immunoglobulin G (IgG), IgM, C3, C4d, and platelets (18). Histopathological features of AHXR are similar to those of HAR (19).

The major HAR xenoantigen is galactose- $\alpha 1,3$-galactose $(\alpha-$ Gal), which is expressed by $\alpha 1,3$-galactosyltransferase $(\alpha 1,3 \mathrm{GalT}$; also known as GGTA1) $(20,21)$. GGTA1 is functional in most mammals, including pigs, but not in humans or Old World monkeys (22). In human blood, $\sim 1 \%$ of all circulating antibodies are directed against $\alpha$-Gal epitopes $(23,24)$. These natural anti- $\alpha$ Gal antibodies are universally induced during neonatal life by gut bacteria that expressed GGTA1 (25). Pig-to-NHP experiments have shown that Gal-specific antibodies could cause HAR and AHXR (26). Kidneys and hearts from GGTA1 knockout (GTKO) pigs were transplanted into NHP but were rejected through antibody-meditated rejection over several days $(18,27)$. These data suggest that non-Gal antigens cause AHXR, and non-Gal antigens present an additional barrier to the transplantation of organs from GTKO pigs to humans.

To date, two non-Gal epitopes have been identified: $N$ glycolylneuraminic acid (Neu5Gc) and the SDa blood group (28, 29). The enzyme which is encoded by CMP-N-acetylneuraminic acid hydroxylase (CMAH) gene hydroxylase Neu5Ac to produce the Neu5Gc (30). Humans do not express Neu5Gc because of a DNA mutation that causes them to lack functional $\mathrm{CAMH}$ (31), but it is synthesized in some mammals, including pigs and Old World Monkeys (32). Murine deficiency of Neu5Gc and Gal epitopes in xenogeneic cells attenuates the cytotoxicity of naturally occurring antibodies in human sera (33). Evidence in vitro suggests that the antibody against Nec5Gc from human serum could bind to porcine Neu5Gc (34). Anti-Neu5Gc antibodies can be induced in humans after dietary intake of porcine tissues from diet (35). The SDa blood group, which is produced by beta-1,4-N-acetyl-galactosaminyltransferase 2 ( $\beta 4$ GALNT2), is the third examined xenogeneic antigen (29). This antigen was first identified using complementary DNA expression libraries from GGTA1-KO pigs and screening of serum from baboons that had rejected GGTA1-KO pig hearts (36). The inactivation of $\beta 4$ GALNT2 considerably reduces the level of human non-Gal IgM and IgG binding to pig peripheral blood mononuclear cells, suggesting the presence of human antibodies that bind to the porcine glycan produced by the $\beta 4$ GALNT2 gene (34). Therefore, these two non-Gal epitopes may be key barriers to clinical xenotransplantation.

\section{Cellular Xenograft Rejection}

Unlike HAR and AHXR, cellular xenograft rejection is relevant to both whole organ grafts and cellular grafts. It results in rejection that may occur days to weeks after transplantation (37). Cellular rejection of a xenograft can be mediated by innate and adaptive immune responses. These consist of NK cells, macrophages, neutrophils, dendritic cells, T cells, and B cells.

\section{Natural Killer Cells in Xenograft Rejection}

NK cells are a subset of lymphocytes of the innate immune system. NK cell infiltrates were found in pig organs perfused with human blood ex vivo $(38,39)$ and in pig-to-NHP xenografts $(40$, 41 ), suggesting that NK cells participate in xenograft rejection.

Subsequently the molecular mechanisms involved in human NK cell-porcine endothelial cell interactions have been studied 
extensively [review in (42)]. Xenograft rejection is mediated by NK cells through direct NK cytotoxicity or by antibodydependent cellular cytotoxicity mechanisms (Figure 2A). In the direct NK cytotoxicity pathway, through interaction of activating receptors and ligand, NK cells release lytic granules, leading to the lysis of the donor endothelial cell $(43,44)$. The direct cytotoxicity of NK cell is tightly regulated by the balance between activating and inhibiting signal pathways mediated by a variety of NK cell receptors (45). The activating NK receptors NKG2D (46) and pULBP-1 (47) bind to its pig ligand NKp44 and an unidentified molecule, respectively, to trigger lytic granule release. However, the inhibitory receptors on human NK cell, KIR, ILT2, and CD94/NKG2A, poorly recognize the porcine major histocompatibility complex (MHC) class I molecule, swine leukocyte antigen I, consequently disabling inhibitory signals for NK cell activation $(48,49)$. The destruction of pig endothelial cells occurs by the recognition of receptors on NK cells. The natural and elicited antibodies deposits on the graft endothelium are recognized by $\mathrm{Fc}$-fraction (FcRs) on NK cells (Figure 2A). Interaction between FcRs and antibodies causes cytotoxic granules to release from NK cells and, in turn, to trigger target cell apoptosis (50). In addition to xenoantibodies bound on the endothelium, the induced antiswine leukocyte antigen (antiSLA) class I antibodies are recognized by NK cells, also leading to antibody-dependent cellular cytotoxicity (51).

Removal of $\alpha$-Gal epitopes protects porcine endothelial cells from complement-induced lysis and primate antipig antibodies meditated destruction but does not resolve the adhesion of NK cells and direct NK cytotoxicity (52). These data suggest that $\alpha$ Gal residues on porcine cells may not be involved in the increased adhesion and direct cytotoxic activity of human NK cells.

The role of NK cells in xenotransplantation still must be fully elucidated. The majority of knowledge on NK in xenotransplantation was generated for in vitro studies and in pig to rodent models. Further in vivo studies on NHPs are required for a better understanding of the role of NK cells in the rejection of porcine cellular and organ xenografts.

\section{Macrophage Cells in Xenograft Rejection}

Macrophages have been found to be involved in the rejection of both organ grafts and cellular grafts (53). A dense macrophage infiltrate was identified in all the rejected xenografts through histologic analysis (54). Macrophage contribute to xenograft rejection by their activity of modulation adaptive immunity and direct cytotoxicity (37). Macrophages activity can be result from xenoreactive $\mathrm{T}$ cells. $\mathrm{T}$ cells recruit and activate macrophages, causing infiltration, and the destruction of xenografts by macrophages. This process, in turn, leads to T-cell response amplification $(55,56)$. In addition, macrophages can be active by direct interaction between donor endothelial antigens and receptors on the surface of macrophage (Figure 2B) (57). Macrophages perform direct toxic effects mediated by the production of proinflammatory cytokines [e.g., tumor necrosis factor alpha (TNF- $\alpha$ ), interleukin-1 (IL-1), and IL-6] that are secreted by macrophages (58). Therefore, the regulation of macrophage activation should improve xenograft survival.
A number of inhibitory receptors have been reported to inhibit phagocytic activity. Among many pathways, the signaling regulatory protein (SIRP- $\alpha$ )-CD47 signaling pathway is an important negative pathway to macrophages. SIRP- $\alpha$ recognizes CD47 as a marker of self, preventing macrophagemediated autologous phagocytosis $(59,60)$. Research has indicated that interspecies incompatibility between CD47 and SIRP- $\alpha$ contributes to the rejection of xenogeneic cells by macrophages (61) and that binding porcine CD47 does not supply the inhibiting signal through SIRP- $\alpha$ to human macrophages (62). Other inhibitory molecule, such as CD200 (63), immunoglobulin-like transcript 3 (64), and Ig-like receptor B (65), have been reported involved in macrophage function. However, whether incompatibility between these molecules on pig cells and their receptors on primate macrophages promotes macrophage activation in xenogeneic immune responses requires further evaluation.

\section{T-Cell Response}

$\mathrm{T}$ lymphocytes are likely important mediators of acute cellular rejection. Similar to allotransplantation, $\mathrm{T}$ cells are activated through both direct and indirect pathways after xenotransplantation (Figure 2C) (66). In the direct pathway, pig antigen-presenting cells (APCs) directly active primate T cells. The interaction between primate T-cell receptors and SLA class I and II peptide complexes results in T-cell-mediated cytotoxicity against the xenograft vascular endothelium. The two cell types likely to be donor APCs are the migratory passenger leukocytes and porcine endothelial cells constitutively expressing CD80/86 (67). In the indirect pathway, T cells activation occurs through donor-derived peptides presented by recipient APCs. Pig xenoantigens are recognized by MHC class II of the recipient and presented to host $\mathrm{T}$ cells (66). This process, in turn, leads to $\mathrm{CD} 4^{+} \mathrm{T}$-cell stimulation, B-cell activation, de novo antibody production, and humoral xenograft rejection. The cytotoxicity of NK cells and macrophages also can be substantially augmented by cytokines produced by xenoantigen-activated $\mathrm{T}$ cells (12).

Although similar immunological mechanisms can be observed in allotransplantation and xenotransplantation, $\mathrm{T}$-cell responses against pig antigen, especially in indirect responses, are stronger than responses against alloantigen (68). Surprisingly, acute cellular rejection, as seen in the majority of allotransplants, is rarely documented after pig-to-NHP organ xenotransplantation. There are two possible reasons for this result: either humoral rejection is so strong that we cannot observe cell rejection following xenotransplantation, or current immunosuppression therapy is sufficient to control T-cell-mediated response in xenotransplantation (69). T-cell activation requires the binding of the TCR to an MHCpeptide complex on the APC as well as a second costimulatory signal involved in the CD40-CD154 and CD28-CD80/86 pathways (70). The compatibility of cross-species adhesion and costimulation molecules is a critical issue in a xenogeneic context. The strategies to alleviate T-cell rejection in xenografts rely mainly on promoting costimulation and downregulation of MHC expression in porcine cells. In 2000, costimulation blockade-based immunosuppressive therapy was introduced 


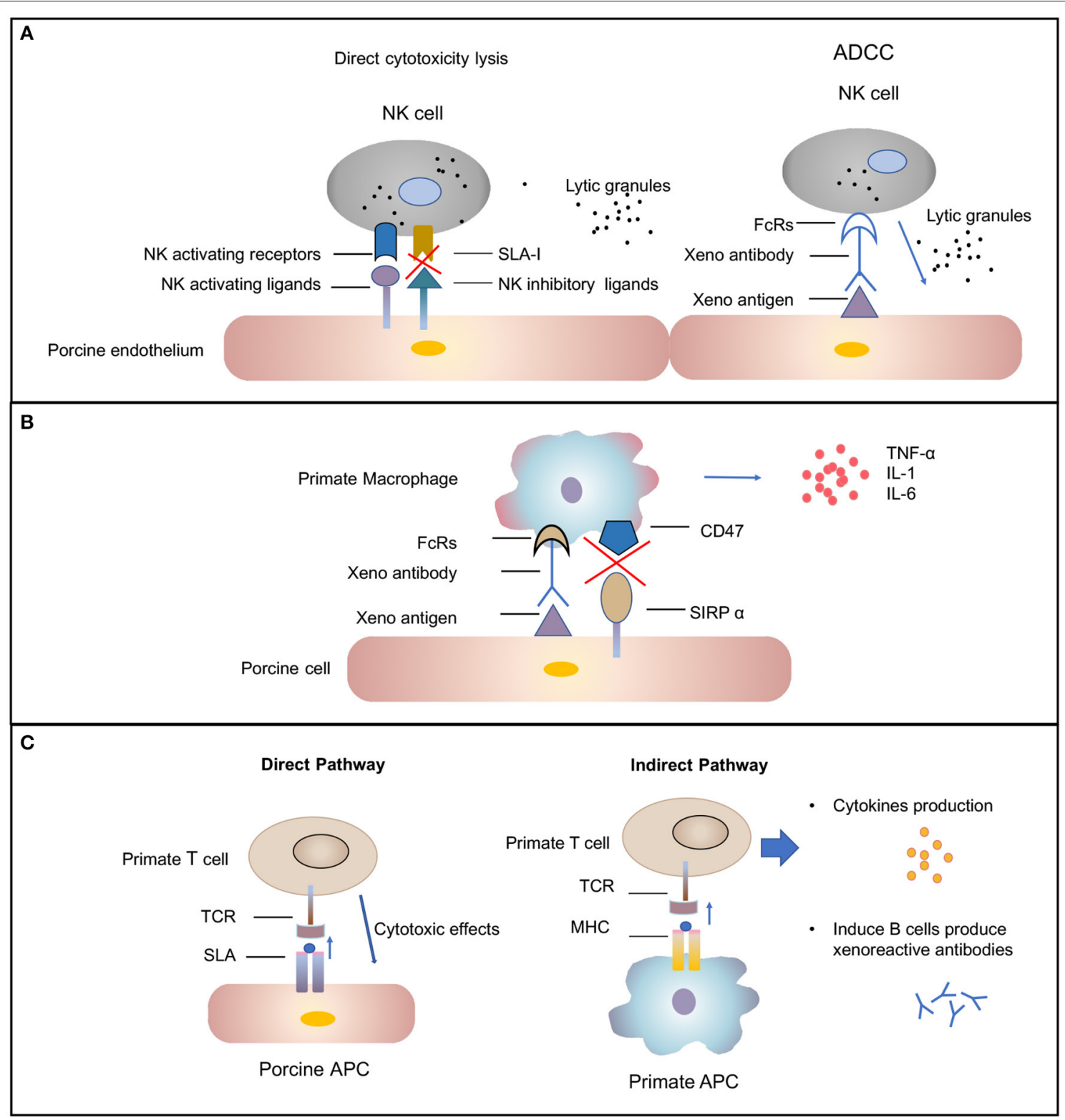

FIGURE 2 | Cellular-mediated rejection. (A) Natural killer (NK) cells-mediated rejection. Xenoantibodies bind to donor endothelial cells with their Fab portion. The Fc fraction of the antibody is recognized by FCRs located on the surface of NK cells, triggering the signaling cascade that leads to NK cell destruction. The release of lytic granules (marked as dark spots) leads to pig endothelial cells lysis. The activating NK cell receptors recognize their ligands on the donor cells and trigger lytic granule release. The inability of swine leukocyte antigen (SLA) class I to interact with human inhibitory NK-cell receptors makes porcine cells highly susceptible to human NK-cell-mediated lysis. (B) Macrophages-mediated rejection. Macrophages can be activated by cytokines [e.g., interferon gamma (IFN- $\gamma$ )] that are produced by xenoreactive T cells contributing to the amplification of the T-cell response (not shown). Macrophage also can also be activated by signals mediated by the Fc receptor for $\operatorname{lgG}(F c \gamma R)$ upon interaction with xenoreactive-antibody-coated porcine cells. Macrophages secrete proinflammatory cytokines [e.g., tumor necrosis factor alpha (TNF- $\alpha$ ), interleukin (IL)-1, and IL-6) that augmented cytotoxicity of macrophages. (C) T-cell response in xenograft rejection. The direct pathway refers to the recognition of antigens presented by pig antigen-presenting cells (APCs) by recipient T cells. The T cell is activated by interaction between T-cell receptors (TCRs) and the SLA I and II peptide complexes. This interaction results in T-cell-mediated cytotoxicity that is directed against the xenograft vascular endothelium. The indirect pathway refers to the recognition of donor-derived peptides on recipient APCs by recipient T cells. The interaction between primate TCRs and major histocompatibility complex (MHC) and porcine peptide complexes leads to primate T-cell response, including cytokines production and induction of B-cell activation.

into xenotransplantation by Buhler et al. (71). The initial agent, anti-CD $154 \mathrm{mAb}$, was highly effective at preventing T-cell response in the pig-to-NHP model (72). Unfortunately, anti-CD $154 \mathrm{mAb}$ was found to be thrombogenic and is currently not available for clinical use (73). In subsequent research, anti-CD40mAb, which also blocks the CD40-CD154 pathway, was found to be equally effective in xenotransplantation $(74,75)$. However, currently available anti-CD28 agent alone may be 
insufficient prevent a T-cell response in NHP models (76). Taken together, the blockade of the CD40-CD154 pathway is a critical component of immunosuppressive agents in the control of xenogeneic $\mathrm{T}$-cell response.

\section{Coagulation Dysregulation}

When HAR, AHXR, and T-cell response are prevented, coagulation dysregulation becomes more obvious following xenograft transplantation and is considered another major barrier to prolonged xenograft survival in NHPs (69). Coagulation dysregulation results in the development of thrombotic microangiopathy in the graft. Features of thrombotic microangiopathy include fibrin deposition and platelet aggregation resulting in thrombosis within the vessels of the graft and eventual ischemic injury $(77,78)$. With the development of coagulation dysregulation, systemic consumptive coagulopathy may be observed in the recipient and lead to the recipient's death, but this phenotype does not occur in all xenograft organs (79).

Coagulation is a complex pathway that involves interactions with inflammation and innate immunity (80). Normally, coagulation occurs continuously within the bloodstream but is restrained by anticoagulants, thus maintaining coagulation balance (81). When endothelial cells are injured, tissue factor (TF) is liberated into circulation, triggering the extrinsic coagulation pathway. The increased coagulation is initiated by TF, which forms complexes with factor VIIa. The coagulation cascade then becomes amplified by the factors shown (VIIa/TF complex, IXa, and Xa), which in turn activate thrombin (81). A network of inhibitory pathways, including tissue factor pathway inhibitor (TFPI) and thrombomodulin (TBM)-protein C (PC) pathway, regulate the coagulation balance (82) (Figure 3A).

In the context of xenotransplantation, the assault by antibodies and complement-activated pig endothelial cells converts endothelial cells from an anticoagulant phenotype to a procoagulant state, leading to vascular destruction, and infiltration by various immune cells (87). Both recipient- and donor-derived $\mathrm{TF}$ contribute to activation of the extrinsic coagulation cascade $(85,88)$. The molecular incompatibilities between primate and pig coagulation-anticoagulation systems exaggerate this process (Figure 3B). The porcine TFPI is not sufficient to inhibit factor Xa of primates and ineffectively shuts down the activation of the major TF (89). Porcine TBM also fails to regulate primate thrombin. Porcine TBM binds human thrombin less strongly and thus does not activate PC (90). Another molecular incompatibility is porcine von Willebrand Factor (pvWF) and primate platelet lycoprotein 1b (GPIb). Even in the absence of shear stress, pvWF spontaneously aggregates primate platelets through GPIb receptors (86). After aberrant GPIb-vWF interaction, intracellular signaling occurs, and platelets are activated. Activated platelets develop thrombosis after being recruited to the place of the endothelial cells' injury, which leads to widespread activation of the coagulation system (91).

Above all, recent advances in the field of xenotransplantation have enabled a better understanding of the immune mechanisms underlying the failure of porcine xenografts. It is vital for xenotransplantation be introduced into clinic. However, many molecular mechanisms underlying xenograft rejection needed further elucidation, especially in pig-to-NHP models. Apparently, considerable "cross-talk" occurs between the cellular and humoral immunology responses and between those responses and the factors responsible for coagulation dysfunction and inflammation in rejected xenografts. As a consequence, diverse strategies are required to overcome the various immunological barriers involved in the rejection of various forms of xenotransplantation procedures.

\section{GENETICALLY MODIFIED PIGS FOR XENOTRANSPLANTATION}

According to studies on immunological rejection and coagulation dysregulation, plenty of genetically modified pigs were generated to bridge cross-species molecular incompatibilities. Since 2009, most of the advances that have been made in the field of xenotransplantation because of the production of genetically engineered pigs. As a result of improvements in gene-editing tools, especially clustered regularly interspaced short palindromic repeats-cas9 (CRIPSR/Cas9), a large variety of genetically modified pigs have been generated, and the production of source pigs with multiple edited genes has become easier and faster (92). In this section, we summarize current genetically modified pigs available for xenotransplantation (Table $\mathbf{1}$ ).

\section{Expression of Human Complement Regulatory Proteins}

Complement activation is a clearly detriment factor in contributing to xenograft failure. One approach is administering an agent to inhibit complement, but such treatment only had a temporary effect and enhanced the risk of infection $(15,109)$. Another approach is engineering genetically modified pigs to overcome immunological rejection. Pigs possess complement regulatory proteins (CRPs) that are similar to those of humans, but pig CRPs are not sufficient to protect pig epithelium cells from human complement-mediated injury. Introduction of human CRPs (hCRPs) (e.g., CD46, CD59, and CD55) into pig cells was suggested to inhibit complement-mediated graft injury. In the 1990s, two independent research groups first proposed the suggestion that production of transgenic pigs expressing the human CRPs CD59 (110) and CD55 (111) to protect from hyperacute xenograft rejection. Then, pigs expressing hCRP were produced by microinjection of DNA into the fertilized egg $(96,97)$. These advances introduced the possibility of genetic modification of the organ-source pig for xenotransplantation. Today, many pigs expressing hCPRs have been produced [reviewed in (112)]. Researches have also demonstrated that expression of hCRPs can inhibit complement-mediated graft injury and prolong xenograft survival time $(113,114)$. Furthermore, studies have also demonstrated that a combination of hCRPs offers greater protection than the expression of just one hCRP $(115,116)$. 


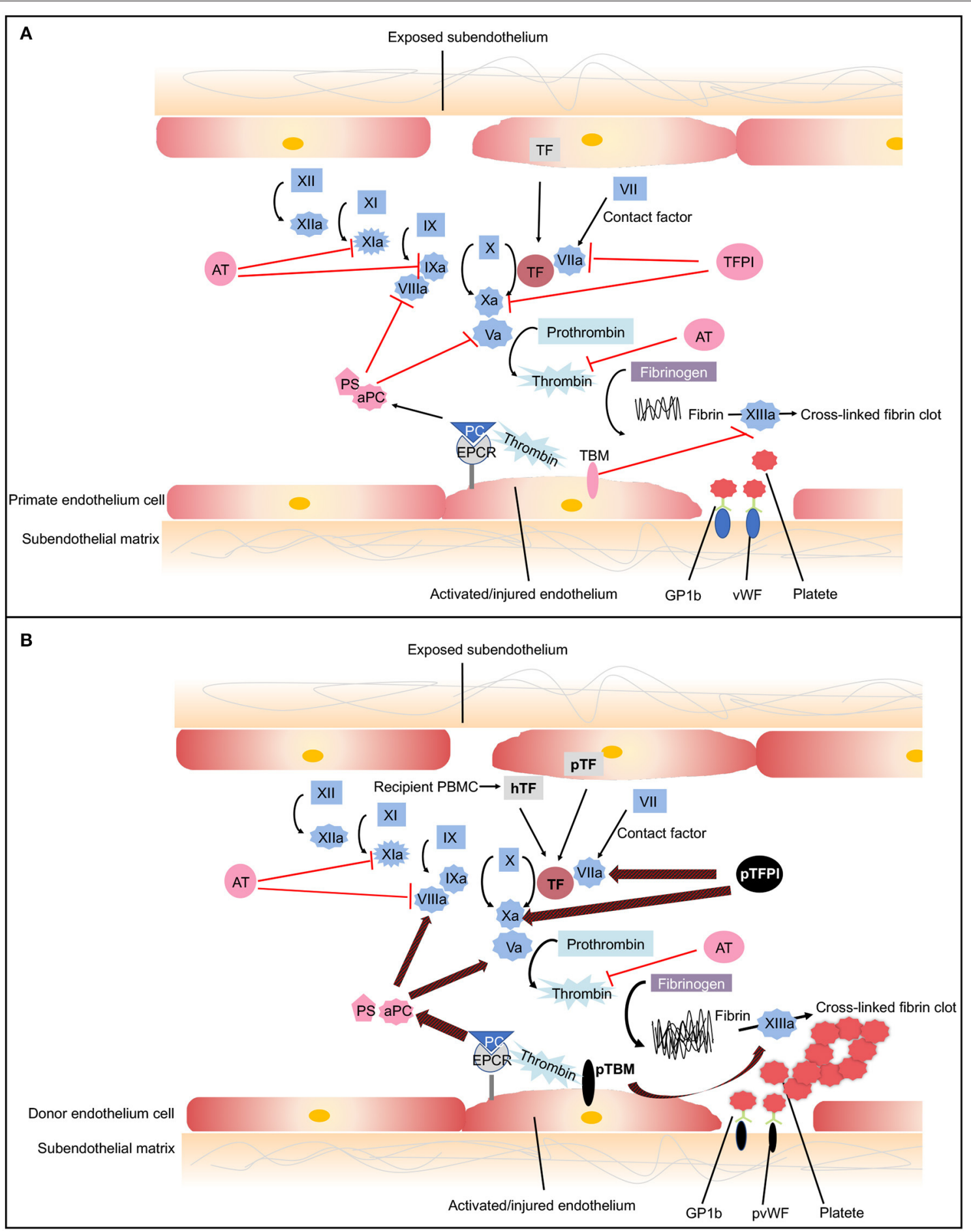

FIGURE 3 | The coagulation cascade related to xenotransplantation. (A) Coagulation cascade in primates. Black arrows designate cascade amplification steps. The coagulation cascade is initiated by tissue factor (TF) (extrinsic pathway) or negatively charged surface contact (intrinsic pathway). TF is expressed by vascular subendothelial cells. When endothelium is damaged, TF is exposed to the circulation and forms complexes with factor VIla, activating factors V and X. Factor Xa converts prothrombin to thrombin. Thrombin then cleaves fibrinogen into fibrin monomers and activates factor XIII, which cross-links fibrin monomers into an insoluble clot. In response to shear stress, von Willebrand Factor (VWF) binds to glycoprotein 1b (GPIb) on platelets leading to platelet activation and adhesion (83). Activated platelet bind to fibrinogen to mediate platelet aggregation and endothelial adherence. Red lines show the natural inhibitors of coagulation. (1) Tissue factor pathway inhibitor (TFPI) inhibits the activation of factor Xa and formats TFPI/Xa, which subsequently inhibits the TF/VIla complex. These processes consequently prevent the formation of thrombin (81). (2) In the thrombomodulin (TBM)-protein C (PC) pathway, TBM serves as a cofactor in the thrombin-induced activation of PC. Endothelial 
FIGURE 3 | protein $C$ receptor (EPCR) is a receptor for PC that enhances its activation. The activated $P C(a P C)$, together with cofactor protein $S$ (PS), suppressing factors Va and VIlla, thereby downregulating thrombin formation and suppressing coagulation cascade (84). (3) Soluble antithrombins (AT) inhibits factors Xla, IXa, Xa, VIla, and thrombin by targeting serine proteases (82). (B) Dysregulated coagulation in pig-to-primate xenotransplantation. Red and black arrows designate incompatibility between pig and primates. When pig endothelium is activated, pig TF is expressed and released into the circulation. After interaction with the pig endothelium, recipient platelets and peripheral blood mononuclear cells (PBMCs) express primate tissue factor (hTF). The porcine TF (pTF) pathway inhibitor is an ineffective inhibitor of the human Xa factor and may ineffectively shut down the activation of the major TF. Pig TBM (pTBM) binds only weakly to primate thrombin, leading to levels of activated PC that are insufficient to inhibit coagulation, resulting in thrombotic microangiopathy in pig grafts within a matter of weeks (85). Porcine WWF spontaneously could aggregate primate platelets through GPIb receptors even in the absence of shear stress (86). After aberrant porcine GPIb-primate vWF interaction, platelets are activated. Small vessels in the graft become occluded by fibrin and platelet aggregation.

TABLE 1 | Genetically modified pigs currently available for xenotransplantation research.

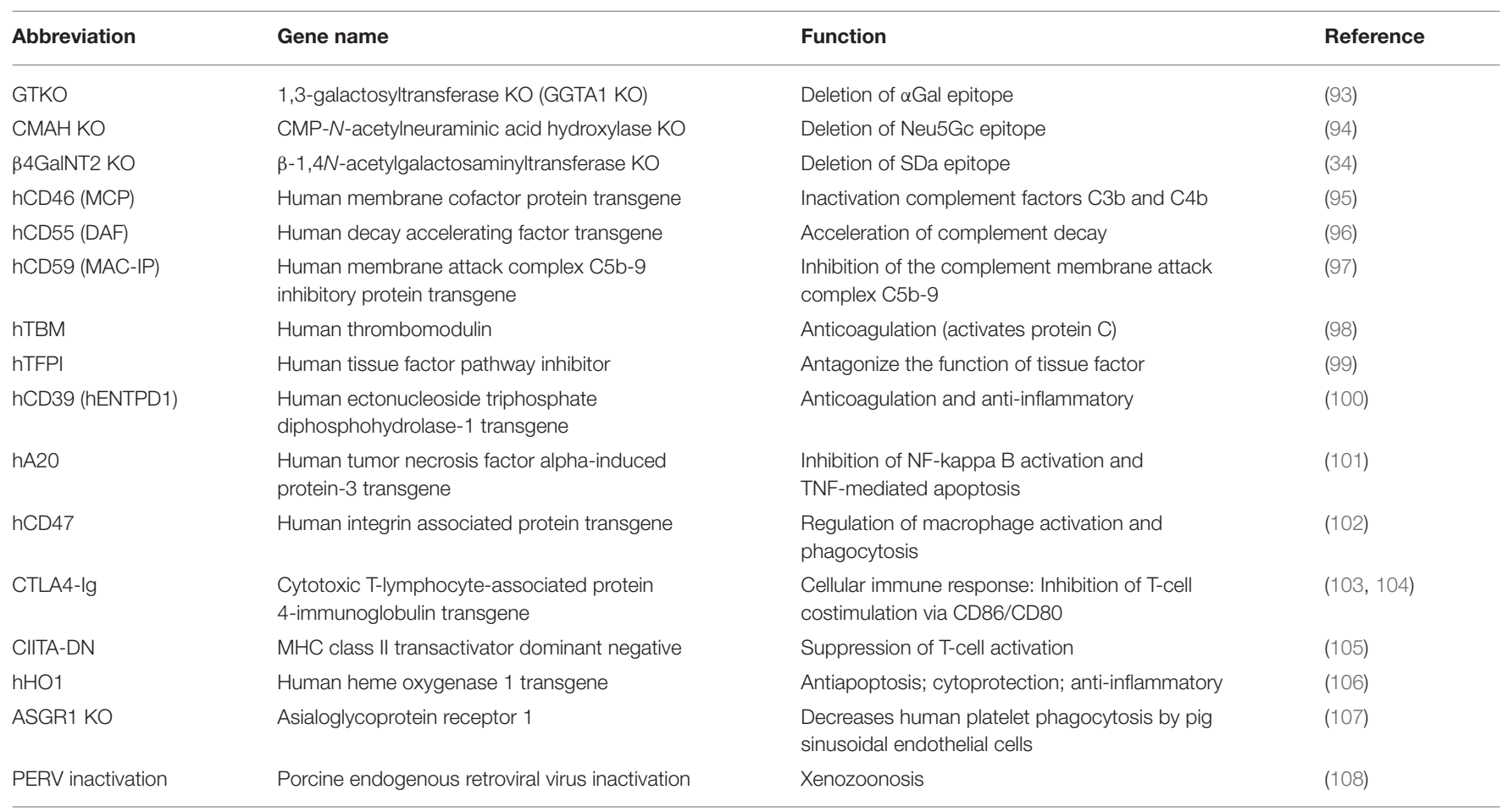

\section{Deleting Xenoreactive Antigens}

Rejection of anti-Gal antibodies can be prevented through plasmapheresis (117) or using immunoaffinity columns (118). However, these approaches have demonstrated only partial success because the graft is lost when antibody levels recover. Pigs with heterozygous GTKO using homologous recombination were produced in $2002(119,120)$, and homozygous GTKO pigs were produced in $2003(93,121)$. Initial studies indicated that GTKO pigs protect xenografts from injury as a result of HAR after heart and kidney transplants to NHPs (78, 122). The production of GTKO donor pigs is a milestone of xenotransplantation field.

In addition to GTKO pigs, genetically modified pigs with GGTA1/CMAH (123) or GGTA1/ B4GalNT2 (124) knockout (DKO) and GGTA1/CMAH/B4GalNT2 triple knockout (TKO) (125) were also produced. A study demonstrated that cells from GGTA1/CMAH DKO pigs bound a reduced human antibody than GTKO pigs (126). Moreover, xenografts from GGTA1/CMAH DKO pigs reduced the consumption of human platelets in the liver model (127). These results suggest that the deletion of Neu5Gc epitope in pigs is crucial for increasing xenograft survival time. In vitro evidence has also suggested that inactivation of the B4GalNT2 gene reduce human antibody binding $(34,128)$. These data indicate that TKO pig organs have proven to be a major advancement compared with GTKO and DKO xenografts following transplantation into human. However, experiments involving xenografts from TKO pigs to NHPs have not been reported, mostly because Old World monkeys express Neu5Gc (129). By contrast, New World monkeys do not express Neu5Gc and are likely to produce anti-Neu5Gc antibodies (130). Therefore, this animal is the preferred candidate model for evaluating the effect of the Neu5Gc deletion xenograft in NHP models.

Today, the importance of $\alpha$-Gal in immunological rejection is clear, GTKO pigs are considered to be the basis for further genetic modifications. Studies have demonstrated that the transplantation of organs from GTKO/hCRP pigs has a more favorable effect than the transplantation of organs from pigs with GTKO or CRP alone $(131,132)$. Although 
expression of hCRP alone does not enable make graft long-term survival, even in the GTKO pigs, the complement system is still activated by ischemia-reperfusion injury. Herein, the deletion of identified xenoantigens with expression of one or more hCRPs in pigs would form the foundation for future clinical trial.

\section{Inhibition of Cellular Xenograft Rejection}

Because of the aforementioned incompatibility between human SIRP- $\alpha$ and pig CD47, genetically engineered pigs expressing human CD47 (hCD47) have the potential to resolve this problem. In vitro, porcine cells expressing hCD47 can reduce their phagocytosis by human macrophages (62). Moreover, the expression of hCD47 in porcine endothelial cells not only suppressed macrophage-mediated cytotoxic activity and inflammatory cytokine (TNF- $\alpha$, IL-1 $\beta$, IL-6) production but also inhibited human T-cell infiltration (133). In vivo, hCD47 expression increased xenogeneic hematopoietic engraftment chimerism in the murine model (102) and prolonged the survival porcine skin grafts in baboons (134). These findings collectively suggest the beneficial role of hCD47 expression in xenografts. However, hCD47 expression did not completely prevent phagocytosis from primate macrophages; therefore, the pathway of xenoantigen-activated macrophages may also need to be suppressed.

Cytotoxic T-lymphocyte-associated antigen (CTLA4) is a costimulatory molecule that blocking B7-CD28 costimulatory pathway (135). Immunosuppression therapy with human CTLA4-immunoglobulin (hCTLA4-Ig) has been shown to extend graft survival during allotransplantation for NHPs (136). Therefore, transgenic pig expression of hCTLA4-Ig is a potential means of preventing T-cell activity. Martin et al. produced transgenic pigs with neuronal expression of hCTLA4-Ig and demonstrated that hCTLA4-Ig protein reduced the proliferation of human $\mathrm{T}$ cells against porcine cells (103). The beneficial effect of hCTL4-Ig expression extended xenograft survival time in a rat skin transplantation model (104) and a NHP neuronal transplantation model (137). These in vivo evidence also suggested that the expression of hCTLA4-Ig alone could not prevent xenograft rejection, which is consistent with the result blocking costimulatory pathway against B7-CD28 only. Transgenic pigs ubiquitously expressing pCTLA4-Ig were also produced (138). However, these pigs were susceptible to infection because of high levels of pCTLA4-Ig expression in the blood. Therefore, the expression of this agent only in specific target cells of the pig is favorable. In addition, T-cell response can be controlled through the deletion of SLA class I (139) or introduction of a mutant human class II transactivator gene (CIITA-DN) in pigs (105), both of which reduce pig antigen presentation in the direct pathway. However, the role of these modified genes in protecting xenograft from rejection response requires further evaluation in NHPs. Moreover, although not the original intention, lacking $\alpha$-Gal antigens or expression of hCRPs has been demonstrated to reduce T-cell response to pig cells $(140,141)$.

\section{Expression of Human Coagulation Regulation Proteins}

Using GTKO/hCRP genetically modified pigs as the source donor, HAR and AHXR have been controlled well in many pigto-NHP model studies $(72,74,142)$. However, both thrombotic microangiopathy and systemic consumptive coagulopathy are increasingly recognized in xenograft and NHP recipients. Therefore, coagulation dysregulation becomes a non-negligible barrier to successful xenotransplantation. The graft vascular endothelial cells enter into a procoagulant state, which cannot be successfully controlled by the pig's anticoagulant factors, resulting in coagulation dysregulation and graft failure. This problem may be resolved by further overexpression of human coagulation regulation proteins, such as TBM, endothelial protein $\mathrm{C}$ receptor (EPCR), TFPI, and CD39 in the organsource animals.

Transgenic expression of hTBM in donor pig is one of most important approaches to overcoming coagulopathy currently. Pig aortic endothelial cells expressing hTBM were reported to substantially suppress prothrombinase activity, delay human plasma clotting time, and exhibit less activity in inducing human platelet aggregation $(143,144)$. In the pig-to-baboon model, hTBM expression on cardiac xenografts confers an independent protective effect for prolonging graft survival time $(145,146)$. Another key player in the anticoagulation system is EPCR, which also mediates anti-inflammatory and cytoprotective signaling (147). Therefore, it is speculated that overexpression of hEPCR in donor pigs is a potential solution to overcoming related barriers, providing potent local antiinflammatory, anticoagulant, and cytoprotective cell signaling. In vitro, cells from GTKO/CD46 pigs that also expressed EPCR reduced platelet aggregation activity (144). Expression of hTFPI is a potential approach to resolving the incompatibility between human $\mathrm{TF}$ and pig TFPI. In vitro study demonstrated that expression of hTFPI can inhibit TF activity (99). CD39 plays a key role in the regulation of coagulation. CD39, which is responsible for catalyzing the degradation of extracellular ATP, ADP, and AMP, can inhibit thrombus formation. One study demonstrated that transgenic hCD39 expression in pigs protected against myocardial ischemia/reperfusion injury in an in vivo model (100). In addition, vWF-deficient donor pigs exhibited prolonged lung graft survival time in NHP models and caused a less substantial platelet decrease in receipts $(148,149)$.

Graft coagulation varies among different xenograft organs after transplantation, perhaps because of differences in vascular structure and protein expression pattern. Recently, considerable progress has been made in cardiac and renal xenotransplantation. However, improvements have been limited in liver and lung xenotransplantation. After pig liver xenotransplantation, severe thrombocytopenia can occur within minutes to hours, which exacerbates coagulation dysfunction, resulting in lethal hemorrhage (150). PvWF is a glycoprotein that plays a key role in the pathogenesis of xenograft failure, especially in pulmonary xenotransplantation, because the lung releases more vWF than the heart or kidneys (151). Moreover, the transcription of genes involved in coagulation, fibrinolysis, and platelet function differs in heart and kidney xenografts, which may account for the different courses of coagulation dysregulation in the 
recipients of these organs (152). Pulmonary xenografts release larger quantities of vWF than do heart and kidney xenografts (148). Meta-analyses suggest that the most influential factors in lung transplantation are EPCR and CD39 rather than TBM and TFPI (153). These data collectively suggest that successful control of coagulation dysregulation in xenotransplantation may require different genetic and pharmacological strategies for different organs.

\section{Expression of Human Anti-inflammatory Proteins}

An increasing amount of evidence suggests that inflammatory response plays a considerable role in graft failure in cases of a condition called systemic inflammatory response in xenograft recipients (154). Therefore, the engineering of donor pigs that express one or more human anti-inflammatory or antiapoptotic genes may be an approach to xenograft protection. Transgenic pigs that express human hemeoxygenase- 1 and human A20 are available $(101,106)$. The expression of human hemeoxygenase-1 reportedly protected porcine kidneys from xenograft rejection in the case of ex vivo perfusion with human blood and transgenic porcine aortic endothelial cells (106). However, several human transgenes, including hHO1, hCD47, and human A20, have been introduced in pigs with multiple genetic manipulations (155).

As discussed above, numbers of genes have been found to be involved in xenograft rejection. Because of the immune response to a pig xenograft cannot be considered in isolation, successful control of immunological rejection in xenotransplantation requires the altering of multiple genes in donor pigs. Genetically modified pigs with multiple genes, with up to seven manipulations, have been produced. The in vivo evaluation of their individual specific benefits will be difficult, and it remains unknown whether the manipulation of so many genes in donor pigs has adverse effects. Therefore, the optimization of combinations of modified genes in donor pigs and evaluation of these xenografts in NHP models are important in further studies.

\section{PIG ORGAN GRAFT SURVIVAL IN NON-HUMAN PRIMATES}

Xenotransplantation has a long history with a number of animal models, including mouse, rat, and NHP, and has been used to reveal the mechanisms of rejection responses $(156,157)$. Old World NHPs are the preferred surrogate for humans in exploring the response to pig xenograft transplantation because of their immunological similarities to humans (6). Today, the pig-to-NHP model is the standard model for testing the primate immune response to organs or tissue from genetically modified pigs and the effect of novel immunosuppressive regimens. It is considered the optimal testing ground for predicting human responses as the final step before a human clinical trial (158). Two comprehensive reviews explored pig solid organ graft survival in an NHP until $2013(159,160)$. More recently, several studies reported key advances in NHP models. In this section, we summarize the studies of solid organs in preclinical models in recent years (Table 2).

\section{Heart Xenotransplantation}

Most studies on pig heart transplantation in NHPs have been heterotopic. The survival time of the graft was only 4-6h following transplant with a wild-type pig heart (165). Since GTKO pigs were introduced in 2003, GTKO only or donor pigs expressing one or more hCRPs have helped to prolong the xenograft survival time [reviewed in (160)]. In 2012, Mohiuddin et al. transplanted GTKO/hCD46 transgenic pig hearts into baboons administered anti-CD154 mAb-based immunosuppression (166). They extended the longest survival for heterotopic cardiac xenografts to 236 days. However, thrombotic microangiopathy was observed in the xenograft, and coagulation dysregulation is likely to be the major obstacle in achieving longer survival rates. Subsequently, same authors used GTKO/hCD46/hTBM donor pigs combined with a CD40 antibody-based immunomodulatory regimen (2C10R4) for heterotopic heart transplantation in pig to NHP models (145). In their experiments, the longest survival time was extended to 945 days with a median survival of 298 days. Furthermore, none of the subjects experienced consumptive coagulopathy or thrombocytopenia. This study demonstrated the efficacy and safety of a CD40 antibody-based immunomodulatory regimen (2C10R4) in recipients and suggested the important role of hTBM in donor pigs.

Although considerable progress has been made in nonlife supporting heart xenotransplantation, the life-supporting heart xenotransplantation is still difficult in NHPs; moreover, it is also vital to justify the potential clinical application of heart xenotransplantation. Until 2018, the longest survival time of life-supporting heart transplantation in pig-to-NHP cases was only 57 days (167). On the bases of previous studies, Langin et al. modified their procedure and reported a survival time of more than 6 months in cases of life-supporting heart xenotransplantation in baboons (161). In their protocol of heart xenotransplantation, two steps were crucial to prolong the survival of functional xenografts in baboons. First, non-ischemic porcine heart preservation was performed instead of cold static storage. Second, detrimental xenograft overgrowth was restricted by a drug called temsirolimus (Table 2). The immunosuppression protocol used in this study seems to have been tolerated by the baboons because of no major immunosuppressionrelated infection observed. Their encouraging data suggest that their method might be safe for use in humans, and their research constitutes vital progress toward making clinical heart xenotransplantation a reality.

\section{Kidney Xenotransplantation}

Although the kidney is transplanted as a vital organ, progress in the use of kidneys in pig-to-NHP models has been slower than that for the use of the heart. Before 2015, life-sustaining pig kidney xenotransplantation was limited to only a few weeks on average, with the longest reported survival in pig-to-NHP models being 90 days [review in (160)]. In 2015, GTKO/hCD55 pigs was used as donors and rhesus macaques with T-cell deletion as recipients with follow-up maintenance therapy of anti-CD154 $\mathrm{mAb}$. Recipients with lower titers of antipig antibodies exhibited prolonged kidney xenograft survival (more than 125 days) 
TABLE 2 | Best survival time of solid organ xenotransplantation from pigs to non-human primates.

\begin{tabular}{|c|c|c|c|c|c|}
\hline Xenograft & $\begin{array}{l}\text { Donor pigs genetic } \\
\text { background }\end{array}$ & Immunosuppressive therapy & Survival time (day) & Year (Reference) & $\begin{array}{l}\text { Initial survival } \\
\text { time (donor pig) }\end{array}$ \\
\hline $\begin{array}{l}\text { Heart } \\
\text { (non-life supporting) }\end{array}$ & GTKO/CD46/TBM & $\begin{array}{l}\text { ATG, anti-CD40mAb, anti-CD20mAb, } \\
\text { MMF, CVF, Solu-Medrol, aspirin, } \\
\text { heparin, Ganciclovir, Cefazolin, } \\
\text { Epogen }\end{array}$ & $\begin{array}{l}\text { Rang from } 159 \text { to } 945 \\
\text { Median: } 298 \text { days } \\
n=5\end{array}$ & $(145)$ & $6 \mathrm{~h}(\mathrm{WT})$ \\
\hline $\begin{array}{l}\text { Heart } \\
\text { (life supporting) }\end{array}$ & GTKO/CD46/TBM & $\begin{array}{l}\text { Anti-CD20mAb, ATG, anti-CD40mAb, } \\
\text { MMF, methylpednisolone, } \\
\text { temsirolimus, steroid cortisone }\end{array}$ & $\begin{array}{l}18,27,40,195 \\
n=5\end{array}$ & $(161)$ & 9 days (hCD55) \\
\hline $\begin{array}{l}\text { Kidney } \\
\text { (life supporting) }\end{array}$ & GTKO/CD55 & Anti-CD154 mAb, MMF, solumedrol & $\begin{array}{l}499,414,>70 \\
n=3\end{array}$ & $(162)$ & 13 days $(\mathrm{WT})$ \\
\hline Lung & GTKO/CD47/CD55 & $\begin{array}{l}\text { ATG, rituximab, anti-CD154 mAb and } \\
\text { mycophenolate mofetil }\end{array}$ & $\begin{array}{l}\mathbf{1 4}, 13,4,2,1 \\
n=5\end{array}$ & $(163)$ & $11 \mathrm{~h}(\mathrm{WT})$ \\
\hline Liver & GTKO & $\begin{array}{l}\text { ATG, anti-CD40mAb, tracrolimus, Cs, } \\
\text { CVF, hPCC }\end{array}$ & $\begin{array}{l}25,29 \\
n=2\end{array}$ & $(164)$ & $84 \mathrm{~h}(\mathrm{WT})$ \\
\hline
\end{tabular}

ATG, antithymocyte globulin; MMF, mycophenolate mofetil; CVF, cobra venom factor; hPCC, human prothrombin complex concentrate.

Bold values represent the longest survival time of xenograft.

(72). Compared with previous reports, features of consumptive coagulopathy and proteinuria were delayed for many months. Iwase et al. also reported the transplantation of a kidney from a GTKO/CD46/CD55/TBM/EPCR/CD39 pig (TBM and CD39 were very poorly expressed in the kidney) to a baboon treated with an anti-CD40mAb-based regimen, and the kidney functioned for 136 days (168). This study suggested that the anti-CD40mAb-based regimen was likely to be of equal benefit to anti-CD154 mAb; it also noted the potential beneficial effects of anti-inflammatory agent. In their later study, kidneys from GTKO/CD46/CD55/EPCR/TFPI/CD47 pigs functioned normally in the baboons until days 237 and 260. Two baboons died from infection rather than from immune rejection, and no features of consumptive coagulopathy were observed (169). They suggested that the expression of EPCR is critical to prevent kidney xenograft from coagulation dysregulation.

In 2018, kidneys from GGTA1/B4GALNT2 DKO pigs were transplanted into rhesus monkeys who were immunosuppressed with T-cell depletion, anti-CD154, mycophenolic acid, and steroids. The longest survival achieved in these recipients with functioning transplants was 435 days (124). However, analysis of xenografted kidneys revealed that antibody-meditated rejection and coagulation dysregulation are still the causes of graft failure. Additional deletion of xenoantigen and introduction of human anticoagulation gene would be required in kidney xenografts. More recently, Kim et al. reported their newest report in pig to rhesus macaque kidney transplantation with the longest survival of a life sustaining xenograft in an NHP (499 days) and consistent survival over 1 year (162). Based on previous study of their group $(72,169)$, GTKO/CD55 pigs were used as donors and rhesus macaques with $\mathrm{CD} 4^{+} \mathrm{T}$-cell deletion and lower titers of antipig antibodies were as recipients. This is the first translation model of life-sustaining kidney xenotransplantation, achieving the longest survival time for pig kidney xenografts in NHP models to date. This study determined that the depletion of the CD4+ T cell before transplantation is necessary for the long-term survival of the xenograft. However, the mechanism that selective CD4+ T-cells depletion was sufficient to protect xenograft remains unknown. Whether additional modification such as SLA class II knockout is necessary for donor pigs requires further investigation.

Another question in kidney xenograft is hypoalbuminemia, which developed from proteinuria and uniformly documented in the early studies. However, only modest proteinuria without accompanying hypoalbuminemia has been observed in NHPs with pig kidney grafts recently. More effective control of immunological rejection by genetically modified pig and immunosuppressive agents might be beneficial for this problem.

\section{Liver Xenotransplantation}

Pig liver xenotransplantation seems to be more difficult to perform compared with heart and kidney xenotransplantation. The relevant molecular mechanisms of xenogeneic rejection involved in liver xenografts are more complex. After liver xenotransplantation, thrombotic microangiopathy in the graft and systemic consumptive coagulopathy appear to be more severe after pig liver xenotransplantation (170).

The first report of pig liver orthotopic xenotransplantation to NHPs dates back to 1968 , at which time immunosuppression was limited and donor pigs were wild type, resulting in a maximum survival of only 3.5 days (171). Since 2010, GTKO and GTKO/hCD46 pigs have been introduced for liver xenotransplantation (172-174). Livers from genetically modified pigs were transplanted into baboons, extending liver graft survival time up to 9 days. The limited survival time of liver xenograft was predominantly due to the development of a lethal coagulopathy. Recently, the survival time for lifesupporting orthotopic GTKO pig liver xenografts was extended to 25 and 29 days with hepatic function in baboons, which represents the longest survival time following pig-to-primate liver xenotransplantation to date $(164,175)$. In their modified experimental protocol, the addition of a costimulation blockade agent, anti-CD40 mAb, was ostensibly critical to prolonging liver survival. Moreover, baboons were treated using a continuous infusion of human prothrombin concentrate complex, an 
exogenous human coagulation factor, to prevent coagulation dysregulation and allow spontaneous platelet count recovery.

\section{Lung Xenotransplantation}

The pig lung is the organ most severely damaged by rapid coagulation dysfunction (176). Most research on lung transplantation has employed ex vivo pig lung xenoperfusion with human donor blood models (177), but this model is limited to only short-term effects, usually those occurring within $4 \mathrm{~h}$ (178). Lung xenotransplantation research has begun to use pigto-NHP models. Nguyen et al. demonstrated that the lungs of GTKO pigs with life support transplanted into baboons were protected from HAR. However, the xenografts were functional for only $3.5 \mathrm{~h}$ because of severe coagulation dysregulation (179). Recently, Watanabe et al. reported that the survival time of NHP recipients of lungs from GTKO/CD47/CD55 transgenic pigs was extended by 14 days $(163,180)$. These studies have demonstrated that the introduction of hCD47 can mitigate acute vascular rejection of lung xenografts and prolong porcine lung transplant survival time in NHP models. However, the limited survival time suggests the necessity of additional strategies in lung xenotransplantation.

Considering the above-mentioned achievements, heart and the kidney may be the first two solid organs to be used for clinical xenotransplantation. The modification of GTKO, hCRP, and hTBM may be indispensable in the donor pigs, at least for heart and kidney xenografts. In addition, a new problem of rapid and detrimental growth of xenografts after transplantation has emerged. This problem has been observed in both heart and kidney xenotransplantation $(124,161)$. The combination approaches of therapeutic reduction in blood pressure, reduction in corticosteroid dose, and administration of the MTOR inhibitor appeared to successfully prevent this problem. Moreover, the mechanisms of appropriate xenograft size require further study. The miniature pig as the donor animal may be necessary for the solid xenograft. Although some progress has been made in lung and liver xenotransplantation, survival time is limited, and preclinical results suggest that new genetic engineering and immunosuppression strategies must be developed before considering a transition to clinical trials.

\section{PORCINE ENDOGENOUS RETROVIRUSES IN XENOTRANSPLANTATION}

A major concern in the field of xenotransplantation is the transmission of porcine pathogens to human recipients. Most porcine viruses, bacteria, and fungi can be eliminated by the selection of negative donor animals, breeding in sterile and isolated conditions, early weaning, and embryo transfer (181, 182). However, such strategies are impossible in the case of porcine endogenous retroviruses (PERVs) because PERVs are integrated into the porcine genome with multiple copies (183) and the number of PERV proviruses varies among pig breeds and organs, ranging from 1 to more than 100 (184). PERVs can be divided into three subtypes: PERV-A, PERV$\mathrm{B}$, and PERV-C (185). PERV-A and PERV-B are present in all pig breeds, whereas PERV-C is present in only some pigs (186). Recombinant virus PERV-A/C exhibits increased infectivity toward human cells (187). Therefore, the International Xenotransplantation Association recommends that the donor pig for xenotransplantation be free of PERV-C (188).

No consensus has yet been reached regarding whether it is necessary to guarantee PERV inactivation in donor pigs by genetic manipulation $(189,190)$. PERV transmission of pig-tohuman and human-to-human cells was detected in several in vitro studies $(108,191)$. However, the infection was only observed in certain types of cells, as PERVs are unable to infect certain cell types because of the absence of a functional receptor on most cell surfaces (182). Furthermore, cellular restriction factors, such as APOBEC3G, play a key role in preventing PERV infection. Primary cells expressing APOBEC3G are difficult to infect. By contrast, HEK 293 cells, which are the most susceptible to PERV infection, do not express APOBEC3G (192).

To the best of our knowledge, PERV transmission has not yet been reported in preclinical pig-to-NHP models or in clinical cells transplantations to humans (193). If necessary, PERV inactivation can also be accomplished by genetically engineering pig donors. Early studies reported that PERV activation can be suppressed by RNA interference technology $(194,195)$. In 2015, Yang et al. inactivated all PERV-A and PERV-B genomes in PERV-C-free porcine cells using CRISPR/Cas9. The engineered cells reduced PERV transmission to human cells in vitro (196). In 2017, the same group inactivated all PERVs in a porcine primary cell line and generated healthy PERV-inactivated pigs through somatic cell nuclear transfer (108). These pigs provide a new strategy that eliminates the potential risk of PERVs in xenotransplantation. However, the susceptibility of these pigs to reinfection by PERV remains unclear. Godehardt et al. recently discovered that CRISPR/Cas9 PERV-inactivated cell line PK15 still produced impaired viral particles, although these virions were no longer infectious. The mutated PK15 cells are protected from the reinfection by PERV (197). However, these results were obtained through a monitoring period only up to 55 days, the reinfectivity remains a concern, and the persistent information and observation in PERV-inactivated pigs are necessary.

\section{SUMMARY AND PERSPECTIVE}

With recent achievements and the accumulation of experience with xenotransplantation in preclinical research, the first-inhuman clinical trial may be possible in the near future. It is an inevitable trend that pigs modified with multiple genes are to be used as donor animals for xenotransplantation. New gene-editing technologies enable the production of multiple genetically engineered pigs in shorter periods of time and with greater efficiency. Various types of gene-modified pigs already exist, most of which are being tested in preclinical pig-to-NHP xenotransplantation models. In addition, new xenoreactive antigens are continually being discovered (198, 199), from which new knockout and transgenic pigs may be generated. Although assessment of current genetically modified pigs combined with immunosuppressive therapy in 
NHP models is complex and expensive, we agree with the opinion that substantial results should be obtain in NHP models before clinic application. Data and experience based on studies with NHP models suggest that combining various genetically modified pigs with different immunosuppressive therapies is necessary for the effective transplantation of different organs. Therefore, determining the optimal genetically engineered organ-source pig and immunosuppressive regimen strategy in pig-to-NHP models is a key step toward further clinical study.

Questions regarding the regulatory challenges and ethical concerns regarding clinical xenotransplantation are being asked worldwide. In 2003, the US Food and Drug Administration published comprehensive guidelines for xenotransplantation (http://www.fda.gov/cber/guidelines.htm). Scientists suggest that national regulatory authorities worldwide should reconsider guidelines and regulations regarding xenotransplantation so as to better enable design and safe conduction of informative clinical trials of xenotransplantation when supported by preclinical data (200). The current research makes some progress in meeting the criteria outlined by the recommendations of the International Society for Heart and Lung Transplantation published in 2000 (201). However, it is unclear which regulatory agencies consider current evidence to be sufficient for moving forward with clinical xenotransplantation.

An alternative potential approach that could alleviate the current shortage of human organs for transplantation is to create human-animal chimeras through various techniques, including stem cell biotechnology, regenerative medicine, and blastocyst

\section{REFERENCES}

1. Pan D, Liu T, Lei T, Zhu H, Wang Y, Deng S. Progress in multiple genetically modified minipigs for xenotransplantation in China. Xenotransplantation. (2019) 26:e12492. doi: 10.1111/xen.12492

2. Aristizabal AM, Caicedo LA, Martinez JM, Moreno MGJE. Clinical xenotransplantation, a closer reality: literature review. Cir Esp. (2017) 95:6272. doi: 10.1016/j.cireng.2017.03.007

3. Najarian JS. Experimental xenotransplantation: a personal history. Xenotransplantation. (2003) 10:10-5. doi: 10.1034/j.1399-3089.2003.01082.x

4. Deschamps JY, Roux FA, Sai P, Gouin E. History of xenotransplantation. Xenotransplantation. (2005) 12:91-109. doi: 10.1111/j.1399-3089.2004.00199.x

5. Cooper DKC, Ekser B, Tector AJ. A brief history of clinical xenotransplantation. Int $J$ Surg. (2015) 23(Pt B):205-10. doi: 10.1016/j.ijsu.2015.06.060

6. Cooper DKC, Gaston R, Eckhoff D, Ladowski J, Yamamoto T, Wang L, et al. Xenotransplantation-the current status and prospects. Br Med Bull. (2018) 125:5-14. doi: 10.1093/bmb/ldx043

7. Cooper DK, Gollackner B, Sachs DH. Will the pig solve the transplantation backlog? Annu Rev Med. (2002) 53:133-47. doi: 10.1146/annurev.med.53.082901.103900

8. Laurencin CT, El-Amin SF. Xenotransplantation in orthopaedic surgery. J Am Acad Orthop Surg. (2008) 16:4-8. doi: 10.5435/00124635-200801000-00002

9. Zhang MC, Liu X, Jin Y, Jiang DL, Wei XS, Xie HT. Lamellar keratoplasty treatment of fungal corneal ulcers with acellular porcine corneal stroma. Am J Transplant. (2015) 15:1068-75. doi: 10.1111/ajt.13096

10. Cascalho M, Platt JL. Xenotransplantation and other means of organ replacement. Nat Rev Immunol. (2001) 1:154-60. doi: 10.1038/35100578 complementation $(202,203)$. In addition, another approach to generating organs by $3 \mathrm{D}$ printing technology and decellularized scaffolds in vitro is currently available. Lee et al. described a 3D printing technique for building collagen scaffolds for the human heart spanning from the capillary scale to the full-organ scale. They demonstrated that cells could be embedded in the collagen to construct functional tissue and organs in vitro (204). To date, none of these approaches have reached the stage of testing on NHPs. We hope and believe that these approaches and xenotransplantation will complement each other in clinical application and collectively solve the problem of human organ shortage.

\section{AUTHOR CONTRIBUTIONS}

CQ and TL conceived the idea. TL wrote the manuscript. CQ, BY, and RW revised the manuscript.

\section{FUNDING}

This research was funded by CAMS Innovation Fund for Medical Science (CIFMS), grant number CIFMS 2017-12M-2-005 and CIFMS 2016-12M-2-001.

\section{ACKNOWLEDGMENTS}

We also sincerely thank Dr. Zhiqi Song, Dr. Li, Dr. Yu Zhang, Dr. Xinpei Wang, and Wallace Academic Editing for editing the English text of a draft of this manuscript.

11. Cooper DK, Human PA, Lexer G, Rose AG, Rees J, Keraan M, et al. Effects of cyclosporine and antibody adsorption on pig cardiac xenograft survival in the baboon. J Heart Transplant. (1988) 7:238-46.

12. Yang YG, Sykes M. Xenotransplantation: current status and a perspective on the future. Nat Rev Immunol. (2007) 7:519-31. doi: 10.1038/nri2099

13. Platt JL, Fischel RJ, Matas AJ, Reif SA, Bolman RM, Bach FH. Immunopathology of hyperacute xenograft rejection in a swine-to-primate model. Transplantation. (1991) 52:214-20. doi: 10.1097/00007890-199108000-00006

14. Schuurman HJ, Cheng J, Lam T. Pathology of xenograft rejection: a commentary. Xenotransplantation. (2003) 10:293-9. doi: 10.1034/j.1399-3089.2003.02092.x

15. Kobayashi T, Taniguchi S, Neethling FA, Rose AG, Hancock WW, Ye $\mathrm{Y}$, et al. Delayed xenograft rejection of pig-to-baboon cardiac transplants after cobra venom factor therapy. Transplantation. (1997) 64:1255-61. doi: 10.1097/00007890-199711150-00005

16. Gollackner B, Goh SK, Qawi I, Buhler L, Knosalla C, Daniel S, et al. Acute vascular rejection of xenografts: roles of natural and elicited xenoreactive antibodies in activation of vascular endothelial cells and induction of procoagulant activity. Transplantation. (2004) 77:1735-41. doi: 10.1097/01.TP.0000131167.21930.B8

17. Ekser B, Cooper DK. Overcoming the barriers to xenotransplantation: prospects for the future. Expert Rev Clin Immunol. (2010) 6:219-30. doi: 10.1586/eci.09.81

18. Chen G, Qian H, Starzl T, Sun H, Garcia B, Wang X, et al. Acute rejection is associated with antibodies to non-Gal antigens in baboons using Galknockout pig kidneys. Nat Med. (2005) 11:1295-8. doi: 10.1038/nm1330

19. Cooper DKC, Ekser B, Tector AJ. Immunobiological barriers to xenotransplantation. Int $J$ Surg. (2015) 23(Pt $\quad$ B):211-6. doi: 10.1016/j.ijsu.2015.06.068 
20. Good AH, Cooper DK, Malcolm AJ, Ippolito RM, Koren E, Neethling FA, et al. Identification of carbohydrate structures that bind human antiporcine antibodies: implications for discordant xenografting in humans. Transplant Proc. (1992) 24:559-62.

21. Kobayashi T, Cooper DK. Anti-Gal, alpha-Gal epitopes, and xenotransplantation. Subcell Biochem. (1999) 32:229-57. doi: 10.1007/978-1-4615-4771-6_10

22. Galili U, Shohet SB, Kobrin E, Stults CL, Macher BA. Man, apes, and old world monkeys differ from other mammals in the expression of alphagalactosyl epitopes on nucleated cells. J Biol Chem. (1988) 263:17755-62.

23. Galili U. Interaction of the natural anti-Gal antibody with alpha-galactosyl epitopes: a major obstacle for xenotransplantation in humans. Immunol Today. (1993) 14:480-2. doi: 10.1016/0167-5699(93)90261-I

24. Galili U. The alpha-gal epitope and the anti-Gal antibody in xenotransplantation and in cancer immunotherapy. Immunol Cell Biol. (2005) 83:674-86. doi: 10.1111/j.1440-1711.2005.01366.x

25. Galili U, Mandrell RE, Hamadeh RM, Shohet SB, Griffiss JM. Interaction between human natural anti-alpha-galactosyl immunoglobulin G and bacteria of the human flora. Infect Immun. (1988) 56:1730-7. doi: 10.1128/IAI.56.7.1730-1737.1988

26. Lin SS, Hanaway MJ, Gonzalez-Stawinski GV, Lau CL, Parker W, Davis RD, et al. The role of anti-Galalpha1-3Gal antibodies in acute vascular rejection and accommodation of xenografts. Transplantation. (2000) 70:1667-74. doi: 10.1097/00007890-200012270-00002

27. Byrne GW, Stalboerger PG, Davila E, Heppelmann CJ, Gazi MH, McGregor $\mathrm{HC}$, et al. Proteomic identification of non-Gal antibody targets after pig-toprimate cardiac xenotransplantation. Xenotransplantation. (2008) 15:26876. doi: 10.1111/j.1399-3089.2008.00480.x

28. Song KH, Kang YJ, Jin UH, Park YI, Kim SM, Seong HH, et al. Cloning and functional characterization of pig CMP-N-acetylneuraminic acid hydroxylase for the synthesis of $\mathrm{N}$-glycolylneuraminic acid as the xenoantigenic determinant in pig-human xenotransplantation. Biochem J. (2010) 427:179-88. doi: 10.1042/BJ20090835

29. Byrne G, Ahmad-Villiers S, Du Z, McGregor C. B4GALNT2 and xenotransplantation: a newly appreciated xenogeneic antigen. Xenotransplantation. (2018) 25:e12394. doi: 10.1111/xen.12394

30. Paul A, Padler-Karavani V. Evolution of sialic acids: implications in xenotransplant biology. Xenotransplantation. (2018) 25:e12424. doi: 10.1111 /xen. 12424

31. Varki A. Loss of N-glycolylneuraminic acid in humans: Mechanisms, consequences, and implications for hominid evolution. Am J Phys Anthropol Suppl. (2001) 33:54-69. doi: 10.1002/ajpa.10018

32. Bouhours D, Pourcel C, Bouhours JE. Simultaneous expression by porcine aorta endothelial cells of glycosphingolipids bearing the major epitope for human xenoreactive antibodies. (Gal alpha 1-3Gal), blood group $\mathrm{H}$ determinant and N-glycolylneuraminic acid. Glycoconj J. (1996) 13:947-53. doi: 10.1007/BF01053190

33. Basnet NB, Ide K, Tahara H, Tanaka Y, Ohdan H. Deficiency of N-glycolylneuraminic acid and Gal $\alpha 1-3 \mathrm{Gal} \beta 1-4 \mathrm{GlcNAc}$ epitopes in xenogeneic cells attenuates cytotoxicity of human natural antibodies. Xenotransplantation. (2010) 17:440-8. doi: 10.1111/j.1399-3089.2010.00610.x

34. Estrada JL, Martens G, Li P, Adams A, Newell KA, Ford ML, et al. Evaluation of human and non-human primate antibody binding to pig cells lacking GGTA1/CMAH/B4GalNT2 genes. Xenotransplantation. (2015) 22:194-202. doi: $10.1111 /$ xen. 12161

35. Scobie L, Padler-Karavani V, Le Bas-Bernardet S, Crossan C, Blaha J, Matouskova M, et al. Long-term IgG response to porcine Neu5Gc antigens without transmission of PERV in burn patients treated with porcine skin xenografts. J Immunol. (2013) 191:2907-15. doi: 10.4049/jimmunol.1301195

36. Byrne GW, Stalboerger PG, Du Z, Davis TR, McGregor CG. Identification of new carbohydrate and membrane protein antigens in cardiac xenotransplantation. Transplantation. (2011) 91:287-92. doi: 10.1097/TP.0b013e318203c27d

37. Cadili A, Kneteman N. The role of macrophages in xenograft rejection. Transplant Proc. (2008) 40:3289-93. doi: 10.1016/j.transproceed.2008.08.125
38. Inverardi L, Samaja M, Motterlini R, Mangili F, Bender JR, Pardi R Early recognition of a discordant xenogeneic organ by human circulating lymphocytes. J Immunol. (1992) 149:1416-23.

39. Khalfoun B, Barrat D, Watier H, Machet MC, Arbeille-Brassart B, Riess JG, et al. Development of an ex vivo model of pig kidney perfused with human lymphocytes. Anal Xenogeneic Cell Reactions Surg. (2000) 128:44757. doi: $10.1067 / \mathrm{msy} .2000 .107063$

40. Xu H, Gundry SR, Hancock WW, Matsumiya G, Zuppan CW, Morimoto $\mathrm{T}$, et al. Prolonged discordant xenograft survival and delayed xenograft rejection in a pig-to-baboon orthotopic cardiac xenograft model. J Thorac Cardiovasc Surg. (1998) 115:1342-9. doi: 10.1016/S0022-5223(98)70218-1

41. Quan D, Bravery C, Chavez G, Richards A, Cruz G, Copeman L, et al. Identification, detection, and in vitro characterization of cynomolgus monkey natural killer cells in delayed xenograft rejection of hDAF transgenic porcine renal xenografts. Transplant Proc. (2000) 32:936-7. doi: 10.1016/S0041-1345(00)01046-0

42. Puga Yung G, Schneider MKJ, Seebach JD. The role of NK cells in pig-to-human xenotransplantation. J Immunol Res. (2017) 2017:4627384. doi: $10.1155 / 2017 / 4627384$

43. Schneider MK, Forte P, Seebach JD. Adhesive interactions between human NK cells and porcine endothelial cells. Scand J Immunol. (2001) 54:70-5. doi: 10.1046/j.1365-3083.2001.00966.x

44. Matter-Reissmann UB, Forte P, Schneider MK, Filgueira L, Groscurth P, Seebach JD. Xenogeneic human NK cytotoxicity against porcine endothelial cells is perforin/granzyme $B$ dependent and not inhibited by $\mathrm{Bcl}-2$ overexpression. Xenotransplantation. (2002) 9:325-37. doi: 10.1034/j.1399-3089.2002.0 1074.x

45. Watzl C. How to trigger a killer: modulation of natural killer cell reactivity on many levels. Adv Immunol. (2014) 124:137-70. doi: 10.1016/B978-0-12-800147-9.00005-4

46. Lilienfeld BG, Garcia-Borges C, Crew MD, Seebach JD. Porcine UL16binding protein 1 expressed on the surface of endothelial cells triggers human NK cytotoxicity through NKG2D. J Immunol. (2006) 177:2146-52. doi: 10.4049/jimmunol.177.4.2146

47. Forte P, Lilienfeld BG, Baumann BC, Seebach JD. Human NK cytotoxicity against porcine cells is triggered by NKp44 and NKG2D. J Immunol. (2005) 175:5463-70. doi: 10.4049/jimmunol.175.8.5463

48. Sullivan JA, Oettinger HF, Sachs DH, Edge AS. Analysis of polymorphism in porcine $\mathrm{MHC}$ class I genes: alterations in signals recognized by human cytotoxic lymphocytes. J Immunol. (1997) 159:2318-26.

49. Long EO, Kim HS, Liu D, Peterson ME, Rajagopalan S. Controlling natural killer cell responses: integration of signals for activation and inhibition. Annu Rev Immunol. (2013) 31:227-58. doi: 10.1146/annurev-immunol-020711-075005

50. Resch T, Fabritius C, Ebner S, Ritschl P, Kotsch K. The role of natural killer cells in humoral rejection. Transplantation. (2015) 99:1335-40. doi: 10.1097/TP.0000000000000757

51. Martens GR, Reyes LM, Li P, Butler JR, Ladowski JM, Estrada JL, et al. Humoral reactivity of renal transplant-waitlisted patients to cells from GGTA1/CMAH/B4GalNT2, and SLA class I knockout pigs. Transplantation. (2017) 101:e86-92. doi: 10.1097/TP.00000000000 01646

52. Baumann BC, Forte P, Hawley RJ, Rieben R, Schneider MK, Seebach JD. Lack of galactose-alpha-1,3-galactose expression on porcine endothelial cells prevents complement-induced lysis but not direct xenogeneic NK cytotoxicity. J Immunol. (2004) 172:6460-7. doi: 10.4049/jimmunol.172.10.6460

53. Candinas D, Belliveau S, Koyamada N, Miyatake T, Hechenleitner $\mathrm{P}$, Mark W, et al. $\mathrm{T}$ cell independence of macrophage and natural killer cell infiltration, cytokine production, and endothelial activation during delayed xenograft rejection. Transplantation. (1996) 62:1920-7. doi: 10.1097/00007890-199612270-00042

54. Shimizu A, Yamada K, Robson SC, Sachs DH, Colvin RB. Pathologic characteristics of transplanted kidney xenografts. J Am Soc Nephrol. (2012) 23:225-35. doi: 10.1681/ASN.2011040429 
55. Ezzelarab M, Garcia B, Azimzadeh A, Sun H, Lin CC, Hara H, et al. The innate immune response and activation of coagulation in $\alpha 1,3$ galactosyltransferase gene-knockout xenograft recipients. Transplantation. (2009) 87:805-12. doi: 10.1097/TP.0b013e318199c34f

56. Vadori M, Cozzi E. The immunological barriers to xenotransplantation. Tissue Antigens. (2015) 86:239-53. doi: 10.1111/tan.12669

57. Basker M, Alwayn IP, Buhler L, Harper D, Abraham S, Kruger Gray H, et al. Clearance of mobilized porcine peripheral blood progenitor cells is delayed by depletion of the phagocytic reticuloendothelial system in baboons. Transplantation. (2001) 72:1278-85. doi: 10.1097/00007890-20011015000017

58. El-Ouaghlidi A, Jahr H, Pfeiffer G, Hering BJ, Brandhorst D, Brandhorst $\mathrm{H}$, et al. Cytokine mRNA expression in peripheral blood cells of immunosuppressed human islet transplant recipients. J Mol Med. (1999) 77:115-7. doi: 10.1007/s001090050315

59. Okazawa H, Motegi S, Ohyama N, Ohnishi H, Tomizawa T, Kaneko Y, et al. Negative regulation of phagocytosis in macrophages by the CD47-SHPS-1 system. J Immunol. (2005) 174:2004-11. doi: 10.4049/jimmunol.174.4.2004

60. Barclay AN, Brown MH. The SIRP family of receptors and immune regulation. Nat Rev Immunol. (2006) 6:457-64. doi: 10.1038/nri1859

61. Wang H, VerHalen J, Madariaga ML, Xiang S, Wang S, Lan P, et al. Attenuation of phagocytosis of xenogeneic cells by manipulating CD47. Blood. (2007) 109:836-42. doi: 10.1182/blood-2006-04-019794

62. Ide K, Wang H, Tahara H, Liu J, Wang X, Asahara T, et al. Role for CD47$\operatorname{SIRP} \alpha$ signaling in xenograft rejection by macrophages. Proc Natl Acad Sci USA. (2007) 104:5062-6. doi: 10.1073/pnas.0609661104

63. Hoek RM, Ruuls SR, Murphy CA, Wright GJ, Goddard R, Zurawski SM, et al. Down-regulation of the macrophage lineage through interaction with OX2. (CD200). Science. (2000) 290:1768-71. doi: 10.1126/science.290.5497.1768

64. Cella M, Dohring C, Samaridis J, Dessing M, Brockhaus M, Lanzavecchia A, et al. A novel inhibitory receptor. (ILT3) expressed on monocytes, macrophages, and dendritic cells involved in antigen processing. J Exp Med. (1997) 185:1743-51. doi: 10.1084/jem.185.10.1743

65. Nakamura A, Kobayashi E, Takai T. Exacerbated graft-versus-host disease in Pirb $^{--/--}$mice. Nat Immunol. (2004) 5:623-9. doi: 10.1038/ni1074

66. Scalea J, Hanecamp I, Robson SC, Yamada K. T-cell-mediated immunological barriers to xenotransplantation. Xenotransplantation. (2012) 19:23-30. doi: 10.1111/j.1399-3089.2011.00687.x

67. Griesemer A, Yamada K, Sykes M. Xenotransplantation: immunological hurdles and progress toward tolerance. Immunol Rev. (2014) 258:241-58. doi: $10.1111 /$ imr.12152

68. Hering BJ, Walawalkar N. Pig-to-nonhuman primate islet xenotransplantation. Transpl Immunol. (2009) 21:81-6. doi: 10.1016/j.trim.2009.05.001

69. Cooper DK, Ezzelarab MB, Hara H, Iwase H, Lee W, Wijkstrom M, et al. The pathobiology of pig-to-primate xenotransplantation: a historical review. Xenotransplantation. (2016) 23:83-105. doi: 10.1111/xen.12219

70. Samy KP, Butler JR, Li P, Cooper DKC, Ekser B. The role of costimulation blockade in solid organ and islet xenotransplantation. J Immunol Res. (2017) 2017:8415205. doi: 10.1155/2017/8415205

71. Buhler L, Awwad M, Basker M, Gojo S, Watts A, Treter S, et al. High-dose porcine hematopoietic cell transplantation combined with CD40 ligand blockade in baboons prevents an induced anti-pig humoral response. Transplantation. (2000) 69:2296-304. doi: 10.1097/00007890-200006150-00013

72. Higginbotham L, Mathews D, Breeden CA, Song M, Farris AB III, Larsen CP. Pre-transplant antibody screening and anti-CD154 costimulation blockade promote long-term xenograft survival in a pig-to-primate kidney transplant model. Xenotransplantation. (2015) 22:221-30. doi: 10.1111/xen.12166

73. Bottino R, Knoll MF, Graeme-Wilson J, Klein EC, Ayares D, Trucco M, et al. Safe use of anti-CD154 monoclonal antibody in pig islet xenotransplantation in monkeys. Xenotransplantation. (2017) 24:e12283. doi: 10.1111/xen.12283

74. Mohiuddin MM, Singh AK, Corcoran PC, Hoyt RF, Thomas ML III, Lewis BG, et al. Role of anti-CD40 antibody-mediated costimulation blockade on non-Gal antibody production and heterotopic cardiac xenograft survival in a GTKO.hCD46Tg pig-to-baboon model. Xenotransplantation. (2014) 21:35-45. doi: 10.1111/xen.12066
75. Mohiuddin MM, Singh AK, Corcoran PC, Hoyt RF, Thomas ML III, Lewis $\mathrm{BG}$, et al. One-year heterotopic cardiac xenograft survival in a pig to baboon model. Am J Transplant. (2014) 14:488-9. doi: 10.1111/ajt.12562

76. Iwase H, Ekser B, Satyananda V, Bhama J, Hara H, Ezzelarab M, et al. Pig-to-baboon heterotopic heart transplantation-exploratory preliminary experience with pigs transgenic for human thrombomodulin and comparison of three costimulation blockade-based regimens. Xenotransplantation. (2015) 22:211-20. doi: 10.1111/xen.12167

77. Buhler L, Basker M, Alwayn IP, Goepfert C, Kitamura H, Kawai T, et al. Coagulation and thrombotic disorders associated with pig organ and hematopoietic cell transplantation in nonhuman primates. Transplantation. (2000) 70:1323-31. doi: 10.1097/00007890-200011150-00010

78. Kuwaki K, Tseng YL, Dor FJ, Shimizu A, Houser SL, Sanderson TM, et al. Heart transplantation in baboons using alpha1,3-galactosyltransferase geneknockout pigs as donors: initial experience. Nat Med. (2005) 11:29-31. doi: $10.1038 / \mathrm{nm} 1171$

79. Cooper DK, Bottino R. Recent advances in understanding xenotransplantation: implications for the clinic. Expert Rev Clin Immunol. (2015) 11:1379-90. doi: 10.1586/1744666X.2015.1083861

80. Long AT, Kenne E, Jung R, Fuchs TA, Renne T. Contact system revisited: an interface between inflammation, coagulation, and innate immunity. J Thromb Haemost. (2016) 14:427-37. doi: 10.1111/jth. 13235

81. Furie B, Furie BC. Mechanisms of thrombus formation. N Engl J Med. (2008) 359:938-49. doi: 10.1056/NEJMra0801082

82. Schmelzle M, Schulte Esch J II, Robson SC. Coagulation, platelet activation and thrombosis in xenotransplantation. Curr Opin Organ Transplant. (2010) 15:212-8. doi: 10.1097/MOT.0b013e3283373ccc

83. Ruggeri ZM. Structure and function of von Willebrand factor. Thromb Haemost. (1999) 82:576-84. doi: 10.1055/s-0037-1615883

84. Esmon CT. The discovery of the endothelial cell protein C receptor. J Thromb Haemost. (2010) 8:2-5. doi: 10.1111/j.1538-7836.2009.03660.x

85. Zelaya H, Rothmeier AS, Ruf W. Tissue factor at the crossroad of coagulation and cell signaling. J Thromb Haemost. (2018) 16:1941-52. doi: $10.1111 /$ jth. 14246

86. Pareti FI, Mazzucato M, Bottini E, Mannucci PM. Interaction of porcine von Willebrand factor with the platelet glycoproteins Ib and IIb/IIIa complex. $\mathrm{Br}$ J Haematol. (1992) 82:81-6. doi: 10.1111/j.1365-2141.1992.tb04597.x

87. Pierson RN III, Dorling A, Ayares D, Rees MA, Seebach JD, Fishman JA, et al. Current status of xenotransplantation and prospects for clinical application. Xenotransplantation. (2009) 16:263-80. doi: 10.1111/j.1399-3089.2009.00534.x

88. Lin CC, Chen D, McVey JH, Cooper DK, Dorling A. Expression of tissue factor and initiation of clotting by human platelets and monocytes after incubation with porcine endothelial cells. Transplantation. (2008) 86:702-9. doi: 10.1097/TP.0b013e31818410a3

89. Cowan PJ, d'Apice AJ. Complement activation and coagulation in xenotransplantation. Immunol Cell Biol. (2009) 87:203-8. doi: $10.1038 /$ icb.2008.107

90. Roussel JC, Moran CJ, Salvaris EJ, Nandurkar HH, d'Apice AJ, Cowan PJ. Pig thrombomodulin binds human thrombin but is a poor cofactor for activation of human protein C and TAFI. Am J Transplant. (2008) 8:1101-12. doi: 10.1111/j.1600-6143.2008.02210.x

91. Gawaz M. Role of platelets in coronary thrombosis and reperfusion of ischemic myocardium. Cardiovasc Res. (2004) 61:498-511. doi: 10.1016/j.cardiores.2003.11.036

92. Naeimi Kararoudi M, Hejazi SS, Elmas E, Hellstrom M, Naeimi Kararoudi M, Padma AM, et al. Clustered regularly interspaced short palindromic repeats/Cas9 gene editing technique in xenotransplantation. Front Immunol. (2018) 9:1711. doi: 10.3389/fimmu.2018. 01711

93. Phelps CJ, Koike C, Vaught TD, Boone J, Wells KD, Chen SH, et al. Production of alpha 1,3-galactosyltransferase-deficient pigs. Science. (2003) 299:411-4. doi: 10.1126/science.1078942

94. Kwon DN, Lee K, Kang MJ, Choi YJ, Park C, Whyte JJ, et al. Production of biallelic CMP-Neu5Ac hydroxylase knock-out pigs. Sci Rep. (2013) 3:1981. doi: 10.1038/srep01981 
95. Diamond LE, Quinn CM, Martin MJ, Lawson J, Platt JL, Logan JS. A human CD46 transgenic pig model system for the study of discordant xenotransplantation. Transplantation. (2001) 71:132-42. doi: 10.1097/00007890-200101150-00021

96. Cozzi E, White DJ. The generation of transgenic pigs as potential organ donors for humans. Nat Med. (1995) 1:964-6. doi: 10.1038/nm0995-964

97. Fodor WL, Williams BL, Matis LA, Madri JA, Rollins SA, Knight JW, et al. Expression of a functional human complement inhibitor in a transgenic pig as a model for the prevention of xenogeneic hyperacute organ rejection. Proc Natl Acad Sci USA. (1994) 91:11153-7. doi: 10.1073/pnas.91.23.11153

98. Petersen B, Ramackers W, Tiede A, Lucas-Hahn A, Herrmann D, Barg-Kues B, et al. Pigs transgenic for human thrombomodulin have elevated production of activated protein C. Xenotransplantation. (2009) 16:486-95. doi: 10.1111/j.1399-3089.2009.0 0537.x

99. Lin CC, Ezzelarab M, Hara H, Long C, Lin CW, Dorling A, et al. Atorvastatin or transgenic expression of TFPI inhibits coagulation initiated by antinonGal IgG binding to porcine aortic endothelial cells. J Thromb Haemost. (2010) 8:2001-10. doi: 10.1111/j.1538-7836.2010.03950.x

100. Wheeler DG, Joseph ME, Mahamud SD, Aurand WL, Mohler PJ, Pompili VJ, et al. Transgenic swine: expression of human CD39 protects against myocardial injury. J Mol Cell Cardiol. (2012) 52:958-61. doi: 10.1016/j.yjmcc.2012.01.002

101. Oropeza M, Petersen B, Carnwath JW, Lucas-Hahn A, Lemme E, Hassel P, et al. Transgenic expression of the human A20 gene in cloned pigs provides protection against apoptotic and inflammatory stimuli. Xenotransplantation. (2009) 16:522-34. doi: 10.1111/j.1399-3089.2009.00556.x

102. Tena A, Kurtz J, Leonard DA, Dobrinsky JR, Terlouw SL, Mtango N, et al. Transgenic expression of human CD47 markedly increases engraftment in a murine model of pig-to-human hematopoietic cell transplantation. Am J Transplant. (2014) 14:2713-22. doi: 10.1111/ajt.12918

103. Martin C, Plat M, Nerriere-Daguin V, Coulon F, Uzbekova S, Venturi E, et al. Transgenic expression of CTLA4-Ig by fetal pig neurons for xenotransplantation. Transgenic Res. (2005) 14:373-84. doi: 10.1007/s11248-0047268-4

104. Wang Y, Yang HQ, Jiang W, Fan NN, Zhao BT, Ou-Yang Z, et al. Transgenic expression of human cytoxic T-lymphocyte associated antigen4immunoglobulin. (hCTLA4Ig) by porcine skin for xenogeneic skin grafting. Transgenic Res. (2015) 24:199-211. doi: 10.1007/s11248-014-9833-9

105. Hara H, Witt W, Crossley T, Long C, Isse K, Fan L, et al. Human dominantnegative class II transactivator transgenic pigs - effect on the human anti-pig T-cell immune response and immune status. Immunology. (2013) 140:39-46. doi: $10.1111 /$ imm. 12107

106. Petersen B, Ramackers W, Lucas-Hahn A, Lemme E, Hassel P, Queisser $\mathrm{AL}$, et al. Transgenic expression of human heme oxygenase-1 in pigs confers resistance against xenograft rejection during ex vivo perfusion of porcine kidneys. Xenotransplantation. (2011) 18:355-68. doi: 10.1111/j.1399-3089.2011.00674.x

107. Paris LL, Estrada JL, Li P, Blankenship RL, Sidner RA, Reyes LM, et al. Reduced human platelet uptake by pig livers deficient in the asialoglycoprotein receptor 1 protein. Xenotransplantation. (2015) 22:20310. doi: $10.1111 /$ xen.12164

108. Niu D, Wei HJ, Lin L, George H, Wang T, Lee IH, et al. Inactivation of porcine endogenous retrovirus in pigs using CRISPR-Cas9. Science. (2017) 357:1303-7. doi: 10.1126/science.aan4187

109. Pruitt SK, Kirk AD, Bollinger RR, Marsh HCJr, Collins BH, Levin JL, et al. The effect of soluble complement receptor type 1 on hyperacute rejection of porcine xenografts. Transplantation. (1994) 57:36370. doi: 10.1097/00007890-199402150-00009

110. Dalmasso AP, Vercellotti GM, Platt JL, Bach FH. Inhibition of complementmediated endothelial cell cytotoxicity by decay-accelerating factor. Potential for prevention of xenograft hyperacute rejection. Transplantation. (1991) 52:530-3. doi: 10.1097/00007890-199109000-00029

111. White DJ, Oglesby T, Liszewski MK, Tedja I, Hourcade D, Wang MW, et al. Expression of human decay accelerating factor or membrane cofactor protein genes on mouse cells inhibits lysis by human complement. Transpl Int. (1992) 5(Suppl 1):S648-50. doi: 10.1111/tri.1992.5.s1.648

112. Zhou H, Hara H, Cooper DKC. The complex functioning of the complement system in xenotransplantation. Xenotransplantation. (2019) 26:e12517. doi: $10.1111 /$ xen. 12517

113. Burdorf L, Stoddard T, Zhang T, Rybak E, Riner A, Avon C, et al. Expression of human CD46 modulates inflammation associated with GalTKO lung xenograft injury. Am J Transplant. (2014) 14:1084-95. doi: 10.1111/ajt.12673

114. Liu F, Liu J, Yuan Z, Qing Y, Li H, Xu K, et al. Generation of GTKO diannan miniature pig expressing human complementary regulator proteins hCD55 and hCD59 via T2A peptide-based bicistronic vectors and SCNT. Mol Biotechnol. (2018) 60:550-62. doi: 10.1007/s12033-018-0091-6

115. Huang J, Gou D, Zhen C, Jiang D, Mao X, Li W, et al. Protection of xenogeneic cells from human complement-mediated lysis by the expression of human DAF, CD59 and MCP. FEMS Immunol Med Microbiol. (2001) 31:203-9. doi: 10.1111/j.1574-695X.2001.tb00521.x

116. Zhou CY, McInnes E, Copeman L, Langford G, Parsons N, Lancaster R, et al. Transgenic pigs expressing human CD59, in combination with human membrane cofactor protein and human decay-accelerating factor. Xenotransplantation. (2005) 12:142-8. doi: 10.1111/j.1399-3089.2005.00209.x

117. Alexandre F, Burnod Y, Guyot F, Haton JP. [The cortical column, a new processing unit for cortex-like networks]. C R Acad Sci III. (1989) 309:25964.

118. Taniguchi S, Neethling FA, Korchagina EY, Bovin N, Ye Y, Kobayashi T, et al. In vivo immunoadsorption of antipig antibodies in baboons using a specific Gal(alpha)1-3Gal column. Transplantation. (1996) 62:1379-84. doi: 10.1097/00007890-199611270-00001

119. Dai Y, Vaught TD, Boone J, Chen SH, Phelps CJ, Ball S, et al. Targeted disruption of the alpha1,3-galactosyltransferase gene in cloned pigs. Nat Biotechnol. (2002) 20:251-5. doi: 10.1038/nbt0302-251

120. Lai L, Kolber-Simonds D, Park KW, Cheong HT, Greenstein JL, Im GS, et al. Production of alpha-1,3-galactosyltransferase knockout pigs by nuclear transfer cloning. Science. (2002) 295:1089-92. doi: 10.1126/science.1068228

121. Kolber-Simonds D, Lai L, Watt SR, Denaro M, Arn S, Augenstein ML, et al. Production of alpha-1,3-galactosyltransferase null pigs by means of nuclear transfer with fibroblasts bearing loss of heterozygosity mutations. Proc Natl Acad Sci USA. (2004) 101:7335-40. doi: 10.1073/pnas.0307819101

122. Yamada K, Yazawa K, Shimizu A, Iwanaga T, Hisashi Y, Nuhn M, et al. Marked prolongation of porcine renal xenograft survival in baboons through the use of alpha1,3-galactosyltransferase gene-knockout donors and the cotransplantation of vascularized thymic tissue. Nat Med. (2005) 11:32-4. doi: $10.1038 / \mathrm{nm} 1172$

123. Lutz AJ, Li P, Estrada JL, Sidner RA, Chihara RK, Downey SM, et al. Double knockout pigs deficient in N-glycolylneuraminic acid and galactose $\alpha$-1,3-galactose reduce the humoral barrier to xenotransplantation. Xenotransplantation. (2013) 20:27-35. doi: 10.1111/xen.12019

124. Adams AB, Kim SC, Martens GR, Ladowski JM, Estrada JL, Reyes LM, et al. Xenoantigen deletion and chemical immunosuppression can prolong renal xenograft survival. Ann Surg. (2018) 268:564-73. doi: 10.1097/SLA.0000000000002977

125. Li P, Estrada JL, Burlak C, Montgomery J, Butler JR, Santos RM, et al. Efficient generation of genetically distinct pigs in a single pregnancy using multiplexed single-guide RNA and carbohydrate selection. Xenotransplantation. (2015) 22:20-31. doi: 10.1111/xen.12131

126. Burlak C, Paris LL, Lutz AJ, Sidner RA, Estrada J, Li P, et al. Reduced binding of human antibodies to cells from GGTA1/CMAH KO pigs. Am J Transplant. (2014) 14:1895-900. doi: 10.1111/ajt.12744

127. Butler JR, Paris LL, Blankenship RL, Sidner RA, Martens GR, Ladowski JM, et al. Silencing porcine CMAH and GGTA1 genes significantly reduces xenogeneic consumption of human platelets by porcine livers. Transplantation. (2016) 100:571-6. doi: 10.1097/TP.0000000000001071

128. Zhang R, Wang Y, Chen L, Wang R, Li C, Li X, et al. Reducing immunoreactivity of porcine bioprosthetic heart valves by geneticallydeleting three major glycan antigens, GGTA1/34GalNT2/CMAH. Acta Biomater. (2018) 72:196-205. doi: 10.1016/j.actbio.2018.03.055 
129. Padler-Karavani V, Varki A. Potential impact of the non-human sialic acid $\mathrm{N}$-glycolylneuraminic acid on transplant rejection risk. Xenotransplantation. (2011) 18:1-5. doi: 10.1111/j.1399-3089.2011.00622.x

130. Springer SA, Diaz SL, Gagneux P. Parallel evolution of a self-signal: humans and new world monkeys independently lost the cell surface sugar Neu5Gc. Immunogenetics. (2014) 66:671-4. doi: 10.1007/s00251-014-0795-0

131. McGregor CG, Ricci D, Miyagi N, Stalboerger PG, Du Z, Oehler EA, et al. Human CD55 expression blocks hyperacute rejection and restricts complement activation in Gal knockout cardiac xenografts. Transplantation. (2012) 93:686-92. doi: 10.1097/TP.0b013e3182472850

132. Azimzadeh AM, Kelishadi SS, Ezzelarab MB, Singh AK, Stoddard T, Iwase $\mathrm{H}$, et al. Early graft failure of GalTKO pig organs in baboons is reduced by expression of a human complement pathway-regulatory protein. Xenotransplantation. (2015) 22:310-6. doi: 10.1111/xen.12176

133. Yan JJ, Koo TY, Lee HS, Lee WB, Kang B, Lee JG, et al. Role of human CD200 overexpression in Pig-to-human xenogeneic immune response compared with human CD47 overexpression. Transplantation. (2018) 102:406-16. doi: 10.1097/TP.0000000000001966

134. Tena AA, Sachs DH, Mallard C, Yang YG, Tasaki M, Farkash E, et al. Prolonged survival of pig skin on baboons after administration of pig cells expressing human CD47. Transplantation. (2017) 101:316-21. doi: 10.1097/TP.0000000000001267

135. Koshika T, Phelps C, Fang J, Lee SE, Fujita M, Ayares D, et al. Relative efficiency of porcine and human cytotoxic T-lymphocyte antigen 4 immunoglobulin in inhibiting human CD4+ T-cell responses co-stimulated by porcine and human B7 molecules. Immunology. (2011) 134:386-97. doi: 10.1111/j.1365-2567.2011.03496.x

136. Levisetti MG, Padrid PA, Szot GL, Mittal N, Meehan SM, Wardrip CL, et al. Immunosuppressive effects of human CTLA4Ig in a non-human primate model of allogeneic pancreatic islet transplantation. I Immunol. (1997) 159:5187-91.

137. Aron Badin R, Vadori M, Vanhove B, Nerriere-Daguin V, Naveilhan P, Neveu I, et al. Cell therapy for parkinson's disease: a translational approach to assess the role of local and systemic immunosuppression. Am J Transplant. (2016) 16:2016-29. doi: 10.1111/ajt.13704

138. Phelps CJ, Ball SF, Vaught TD, Vance AM, Mendicino M, Monahan JA, et al. Production and characterization of transgenic pigs expressing porcine CTLA4-Ig. Xenotransplantation. (2009) 16:477-85. doi: 10.1111/j.1399-3089.2009.00533.x

139. Reyes LM, Estrada JL, Wang ZY, Blosser RJ, Smith RF, Sidner RA, et al. Creating class I MHC-null pigs using guide RNA and the Cas9 endonuclease. J Immunol. (2014) 193:5751-7. doi: 10.4049/jimmunol.1402059

140. Wilhite T, Ezzelarab C, Hara H, Long C, Ayares D, Cooper $\mathrm{DK}$, et al. The effect of Gal expression on pig cells on the human T-cell xenoresponse. Xenotransplantation. (2012) 19:56-63. doi: 10.1111/j.1399-3089.2011.00691.x

141. Ezzelarab MB, Ayares D, Cooper DK. Transgenic expression of human CD46: does it reduce the primate T-cell response to pig endothelial cells? Xenotransplantation. (2015) 22:487-9. doi: 10.1111/xen.12209

142. Spiezia L, Boldrin M, Radu C, Bulato C, Bertini D, Bon M, et al. Thromboelastographic evaluation of coagulative profiles in pig-tomonkey kidney xenotransplantation. Xenotransplantation. (2013) 20:89-99. doi: 10.1111/xen.12024

143. Miwa Y, Yamamoto K, Onishi A, Iwamoto M, Yazaki S, Haneda $M$, et al. Potential value of human thrombomodulin and DAF expression for coagulation control in pig-to-human xenotransplantation. Xenotransplantation. (2010) 17:26-37. doi: 10.1111/j.1399-3089.2009.00555.x

144. Iwase H, Ekser B, Hara H, Phelps C, Ayares D, Cooper DK, et al. Regulation of human platelet aggregation by genetically modified pig endothelial cells and thrombin inhibition. Xenotransplantation. (2014) 21:72-83. doi: 10.1111/xen.12073

145. Mohiuddin MM, Singh AK, Corcoran PC, Thomas Iii ML, Clark T, Lewis BG, et al. Chimeric 2C10R4 anti-CD40 antibody therapy is critical for longterm survival of GTKO.hCD46.hTBM pig-to-primate cardiac xenograft. Nat Commun. (2016) 7:11138. doi: 10.1038/ncomms11138

146. Singh AK, Chan JL, DiChiacchio L, Hardy NL, Corcoran PC, Lewis BGT, et al. Cardiac xenografts show reduced survival in the absence of transgenic human thrombomodulin expression in donor pigs. Xenotransplantation. (2019) 26:e12465. doi: 10.1111/xen.12465

147. Bae JS, Yang L, Rezaie AR. Receptors of the protein C activation and activated protein C signaling pathways are colocalized in lipid rafts of endothelial cells. Proc Natl Acad Sci USA. (2007) 104:2867-72. doi: 10.1073/pnas.0611493104

148. Lau CL, Cantu E III, Gonzalez-Stawinski GV, Holzknecht ZE, Nichols TC, Posther KE, et al. The role of antibodies and von Willebrand factor in discordant pulmonary xenotransplantation. Am J Transplant. (2003) 3:106575. doi: 10.1034/j.1600-6143.2003.00190.x

149. Cantu E, Balsara KR, Li B, Lau C, Gibson S, Wyse A, et al. Prolonged function of macrophage, von Willebrand factor-deficient porcine pulmonary xenografts. Am J Transplant. (2007) 7:66-75. doi: 10.1111/j.1600-6143.2006.01603.x

150. Patel MS, Louras N, Vagefi PA. Liver xenotransplantation. Curr Opin Organ Transplant. (2017) 22:535-40. doi: 10.1097/MOT.0000000000000459

151. Holzknecht ZE, Coombes S, Blocher BA, Plummer TB, Bustos M, Lau CL, et al. Immune complex formation after xenotransplantation: evidence of type III as well as type II immune reactions provide clues to pathophysiology. Am J Pathol. (2001) 158:627-37. doi: 10.1016/S0002-9440(10)64004-7

152. Knosalla C, Yazawa K, Behdad A, Bodyak N, Shang H, Buhler L, et al. Renal and cardiac endothelial heterogeneity impact acute vascular rejection in pig-to-baboon xenotransplantation. Am J Transplant. (2009) 9:1006-16. doi: $10.1111 / \mathrm{j} .1600-6143.2009 .02602 . \mathrm{x}$

153. Harris DG, Quinn KJ, French BM, Schwartz E, Kang E, Dahi S, et al. Meta-analysis of the independent and cumulative effects of multiple genetic modifications on pig lung xenograft performance during ex vivo perfusion with human blood. Xenotransplantation. (2015) 22:102-11. doi: 10.1111/xen.12149

154. Ezzelarab MB, Cooper DKC. Systemic inflammation in xenograft recipients. (SIXR): a new paradigm in pig-to-primate xenotransplantation? Int J Surg. (2015) 23(Pt B):301-5. doi: 10.1016/j.ijsu.2015.07.643

155. Fischer K, Kraner-Scheiber S, Petersen B, Rieblinger B, Buermann A, Flisikowska $\mathrm{T}$, et al. Efficient production of multi-modified pigs for xenotransplantation by 'combineering', gene stacking and gene editing. Sci Rep. (2016) 6:29081. doi: 10.1038/srep29081

156. Zhang Z, Bedard E, Luo Y, Wang H, Deng S, Kelvin D, et al. Animal models in xenotransplantation. Exp Opin Investig Drugs. (2000) 9:2051-68. doi: 10.1517/13543784.9.9.2051

157. Wang H. Small animal models of xenotransplantation. Methods Mol Biol. (2012) 885:125-53. doi: 10.1007/978-1-61779-845-0_9

158. Cohen J. The CRISPR animal kingdom. Science. (2019) 365:426-9. doi: 10.1126/science.365.6452.426

159. Lambrigts D, Sachs DH, Cooper DK. Discordant organ xenotransplantation in primates: world experience and current status. Transplantation. (1998) 66:547-61. doi: 10.1097/00007890-199809150-00001

160. Cooper DK, Satyananda V, Ekser B, van der Windt DJ, Hara H, Ezzelarab MB, et al. Progress in pig-to-non-human primate transplantation models. (19982013): a comprehensive review of the literature. Xenotransplantation. (2014) 21:397-419. doi: 10.1111/xen.12127

161. Langin M, Mayr T, Reichart B, Michel S, Buchholz S, Guethoff S, et al. Consistent success in life-supporting porcine cardiac xenotransplantation. Nature. (2018) 564:430-3. doi: 10.1038/s41586-018-0765-Z

162. Kim SC, Mathews DV, Breeden CP, Higginbotham LB, Ladowski J, Martens $\mathrm{G}$, et al. Long-term survival of pig-to-rhesus macaque renal xenografts is dependent on CD4 T cell depletion. Am J Transplant. (2019) 19:2174-85. doi: 10.1111/ajt.15329

163. Watanabe H, Ariyoshi Y, Pomposelli T, Takeuchi K, Ekanayake-Alper DK, Boyd LK, et al. Intra-bone bone marrow transplantation from hCD47 transgenic pigs to baboons prolongs chimerism to $>60$ days and promotes increased porcine lung transplant survival. Xenotransplantation. (2019). doi: 10.1111/xen.12552. [Epub ahead of print]

164. Shah JA, Patel MS, Elias N, Navarro-Alvarez N, Rosales I, Wilkinson RA, et al. Prolonged survival following pig-to-primate liver xenotransplantation utilizing exogenous coagulation factors and costimulation blockade. Am J Transplant. (2017) 17:2178-85. doi: 10.1111/ajt. 14341

165. Simon PM, Neethling FA, Taniguchi S, Goode PL, Zopf D, Hancock WW, et al. Intravenous infusion of Galalpha1-3Gal oligosaccharides in baboons 
delays hyperacute rejection of porcine heart xenografts. Transplantation. (1998) 65:346-53. doi: 10.1097/00007890-199802150-00009

166. Mohiuddin MM, Corcoran PC, Singh AK, Azimzadeh A, Hoyt RF Jr, Thomas $\mathrm{ML}$, et al. B-cell depletion extends the survival of GTKO.hCD46Tg pig heart xenografts in baboons for up to 8 months. Am J Transplant. (2012) 12:763-71. doi: 10.1111/j.1600-6143.2011.03846.x

167. Byrne GW, Du Z, Sun Z, Asmann YW, McGregor CG. Changes in cardiac gene expression after pig-to-primate orthotopic xenotransplantation. Xenotransplantation. (2011) 18:14-27. doi: 10.1111/j.1399-3089.2010.00620.x

168. Iwase H, Liu H, Wijkstrom M, Zhou H, Singh J, Hara H, et al. Pig kidney graft survival in a baboon for 136 days: longest life-supporting organ graft survival to date. Xenotransplantation. (2015) 22:302-9. doi: 10.1111/xen.12174

169. Iwase H, Hara H, Ezzelarab M, Li T, Zhang Z, Gao B, et al. Immunological and physiological observations in baboons with life-supporting genetically engineered pig kidney grafts. Xenotransplantation. (2017) 24:e12293. doi: 10.1111/xen.12293

170. Ekser B, Lin CC, Long C, Echeverri GJ, Hara H, Ezzelarab M, et al. Potential factors influencing the development of thrombocytopenia and consumptive coagulopathy after genetically modified pig liver xenotransplantation. Transpl Int. (2012) 25:882-96. doi: 10.1111/j.1432-2277.2012.0 1506.x

171. Calne RY, White HJ, Herbertson BM, Millard PR, Davis DR, Salaman JR, et al. Pig-to-baboon liver xenografts. Lancet. (1968) 1:1176-8. doi: 10.1016/S0140-6736(68)91869-2

172. Ekser B, Echeverri GJ, Hassett AC, Yazer MH, Long C, Meyer $M$, et al. Hepatic function after genetically engineered pig liver transplantation in baboons. Transplantation. (2010) 90:483-93. doi: 10.1097/TP.0b013e3181e98d51

173. Ekser B, Long C, Echeverri GJ, Hara H, Ezzelarab M, Lin CC, et al. Impact of thrombocytopenia on survival of baboons with genetically modified pig liver transplants: clinical relevance. Am J Transplant. (2010) 10:273-85. doi: 10.1111/j.1600-6143.2009.02945.x

174. Kim K, Schuetz C, Elias N, Veillette GR, Wamala I, Varma M, et al. Up to 9-day survival and control of thrombocytopenia following alphal,3-galactosyl transferase knockout swine liver xenotransplantation in baboons. Xenotransplantation. (2012) 19:256-64. doi: 10.1111/j.1399-3089.2012.00717.x

175. Shah JA, Patel MS, Louras N, Sachs DH, Vagefi PA. Amino acid and lipid profiles following pig-to-primate liver xenotransplantation. Xenotransplantation. (2019) 26:e12473. doi: 10.1111/xen. 12473

176. Ekser B, Ezzelarab M, Hara H, van der Windt DJ, Wijkstrom M, Bottino $\mathrm{R}$, et al. Clinical xenotransplantation: the next medical revolution? Lancet. (2012) 379:672-83. doi: 10.1016/S0140-6736(11)61091-X

177. Laird CT, Burdorf L, French BM, Kubicki N, Cheng X, Braileanu G, et al. Transgenic expression of human leukocyte antigen-E attenuates GalKO.hCD46 porcine lung xenograft injury. Xenotransplantation. (2017) 24:e12294. doi: 10.1111/xen.12294

178. Sahara H, Watanabe H, Pomposelli T, Yamada K. Lung xenotransplantation. Curr Opin Organ Transplant. (2017) 22:541-8. doi: 10.1097/MOT.0000000000000465

179. Nguyen BN, Azimzadeh AM, Zhang T, Wu G, Schuurman HJ, Sachs $\mathrm{DH}$, et al. Life-supporting function of genetically modified swine lungs in baboons. I Thorac Cardiovasc Surg. (2007) 133:1354-63. doi: $10.1016 /$ j.jtcvs.2006.11.043

180. Watanabe H, Sahara H, Nomura S, Tanabe T, EkanayakeAlper DK, Boyd LK, et al. GalT-KO pig lungs are highly susceptible to acute vascular rejection in baboons, which may be mitigated by transgenic expression of hCD47 on porcine blood vessels. Xenotransplantation. (2018) 25:e12391. doi: 10.1111/xen. 12391

181. Hryhorowicz M, Zeyland J, Slomski R, Lipinski, D. Genetically modified pigs as organ donors for xenotransplantation. Mol Biotechnol. (2017) 59:435-44. doi: 10.1007/s12033-017-0024-9

182. Denner J. Why was PERV not transmitted during preclinical and clinical xenotransplantation trials and after inoculation of animals? Retrovirology. (2018) 15:28. doi: 10.1186/s12977-018-0411-8
183. Tonjes RR, Niebert M. Relative age of proviral porcine endogenous retrovirus sequences in Sus scrofa based on the molecular clock hypothesis. J Virol. (2003) 77:12363-8. doi: 10.1128/JVI.77.22.12363-12368.2003

184. Fiebig U, Fischer K, Bahr A, Runge C, Schnieke A, Wolf E, et al. Porcine endogenous retroviruses: quantification of the copy number in cell lines, pig breeds, and organs. Xenotransplantation. (2018) 25:e12445. doi: $10.1111 /$ xen. 12445

185. Ericsson T, Oldmixon B, Blomberg J, Rosa M, Patience C, Andersson G. Identification of novel porcine endogenous betaretrovirus sequences in miniature swine. J Virol. (2001) 75:2765-70. doi: 10.1128/JVI.75.6.2765-2770.2001

186. Blusch JH, Patience C, Martin U. Pig endogenous retroviruses and xenotransplantation. Xenotransplantation. (2002) 9:242-51. doi: 10.1034/j.1399-3089.2002.01110.x

187. Denner J. Recombinant porcine endogenous retroviruses. (PERV-A/C): a new risk for xenotransplantation? Arch Virol. (2008) 153:1421-6. doi: 10.1007/s00705-008-0141-7

188. Hawthorne WJ, Cowan PJ, Buhler LH, Yi S, Bottino R, Pierson RN III, et al. Third WHO global consultation on regulatory requirements for xenotransplantation clinical trials, Changsha, Hunan, China December 12-14, 2018: "The 2018 Changsha Communique" The 10-year anniversary of the international consultation on xenotransplantation. Xenotransplantation. (2019) 26:e12513. doi: 10.1111/xen. 12513

189. Guell M, Niu D, Kan Y, George H, Wang $T$, Lee $I H$, et al. PERV inactivation is necessary to guarantee absence of pig-to-patient PERVs transmission in xenotransplantation. Xenotransplantation. (2017) 24:e12366. doi: 10.1111/xen. 12366

190. Cooper DKC, Ezzelarab M, Iwase H, Hara H. Perspectives on the optimal genetically engineered pig in 2018 for initial clinical trials of kidney or heart xenotransplantation. Transplantation. (2018) 102:1974-82. doi: 10.1097/TP.00000000000 02443

191. Denner J, Specke V, Thiesen U, Karlas A, Kurth R. Genetic alterations of the long terminal repeat of an ecotropic porcine endogenous retrovirus during passage in human cells. Virology. (2003) 314:125-33. doi: $10.1016 / S 0042-6822(03) 00428-8$

192. Denner J. Porcine endogenous retrovirus infection of human peripheral blood mononuclear cells. Xenotransplantation. (2015) 22:151-2. doi: $10.1111 /$ xen. 12150

193. Morozov VA, Wynyard S, Matsumoto S, Abalovich A, Denner J, Elliott R. No PERV transmission during a clinical trial of pig islet cell transplantation. Virus Res. (2017) 227:34-40. doi: 10.1016/j.virusres.2016. 08.012

194. Dieckhoff B, Petersen B, Kues WA, Kurth R, Niemann H, Denner J. Knockdown of porcine endogenous retrovirus. (PERV) expression by PERVspecific shRNA in transgenic pigs. Xenotransplantation. (2008) 15:36-45. doi: 10.1111/j.1399-3089.2008.00442.x

195. Ramsoondar J, Vaught T, Ball S, Mendicino M, Monahan J, Jobst P, et al. Production of transgenic pigs that express porcine endogenous retrovirus small interfering RNAs. Xenotransplantation. (2009) 16:164-80. doi: 10.1111/j.1399-3089.2009. 00525.x

196. Yang L, Guell M, Niu D, George H, Lesha E, Grishin D, et al. Genome-wide inactivation of porcine endogenous retroviruses. (PERVs). Science. (2015) 350:1101-4. doi: 10.1126/science.aad1191

197. Godehardt AW, Fischer N, Rauch P, Gulich B, Boller K, Church GM, et al. Characterization of porcine endogenous retrovirus particles released by the CRISPR/Cas9 inactivated cell line PK15 clone 15. Xenotransplantation. (2019). doi: 10.1111/xen. 12563. [Epub ahead of print].

198. Zhang J, Xie C, Lu Y, Zhou M, Qu Z, Yao D, et al. Potential antigens involved in delayed xenograft rejection in a Ggta1/Cmah Dko pig-to-monkey model. Sci Rep. (2017) 7:10024. doi: 10.1038/s41598-017-10805-0

199. Ladowski J, Martens G, Estrada J, Tector M, Tector J. The desirable donor pig to eliminate all xenoreactive antigens. Xenotransplantation. (2019) 26:e12504. doi: 10.1111/xen.12504 
200. Cooper DKC, Pierson RN III, Hering BJ, Mohiuddin MM, Fishman JA, Denner J, et al. Regulation of Clinical Xenotransplantation-Time for a Reappraisal. Transplantation. (2017) 101:1766-9. doi: 10.1097/TP.00000000000 01683

201. Cooper DK, Keogh AM, Brink J, Corris PA, Klepetko W, Pierson $\mathrm{RN}$, et al. Report of the xenotransplantation advisory committee of the international society for heart and lung transplantation: the present status of xenotransplantation and its potential role in the treatment of end-stage cardiac and pulmonary diseases. $J$ Heart Lung Transplant. (2000) 19:1125-65. doi: 10.1016/S1053-2498(00)0 0224-2

202. Wu J, Greely HT, Jaenisch R, Nakauchi H, Rossant J, Belmonte JC. Stem cells and interspecies chimaeras. Nature. (2016) 540:51-9. doi: 10.1038/nature20573

203. Wu J, Platero-Luengo A, Sakurai M, Sugawara A, Gil MA, Yamauchi $\mathrm{T}$, et al. Interspecies chimerism with mammalian pluripotent stem cells. Cell. (2017) 168:473-86.e415. doi: 10.1016/j.cell.2016. 12.036

204. Lee A, Hudson AR, Shiwarski DJ, Tashman JW, Hinton TJ, Yerneni $\mathrm{S}$, et al. 3D bioprinting of collagen to rebuild components of the human heart. Science. (2019) 365:482-7. doi: 10.1126/science.aa v9051

Conflict of Interest: The authors declare that the research was conducted in the absence of any commercial or financial relationships that could be construed as a potential conflict of interest.

Copyright (C) $2020 \mathrm{Lu}$, Yang, Wang and Qin. This is an open-access article distributed under the terms of the Creative Commons Attribution License (CC BY). The use, distribution or reproduction in other forums is permitted, provided the original author(s) and the copyright owner(s) are credited and that the original publication in this journal is cited, in accordance with accepted academic practice. No use, distribution or reproduction is permitted which does not comply with these terms. 